\title{
GPS-derived estimates of surface mass balance and ocean-induced basal melt for Pine Island Glacier ice shelf, Antarctica
}

\author{
David E. Shean ${ }^{1,2}$, Knut Christianson ${ }^{3}$, Kristine M. Larson ${ }^{4}$, Stefan R. M. Ligtenberg ${ }^{5}$, Ian R. Joughin ${ }^{1}$, \\ Ben E. Smith ${ }^{1}$, C. Max Stevens ${ }^{3}$, Mitchell Bushuk ${ }^{6}$, and David M. Holland ${ }^{7,8}$ \\ ${ }^{1}$ Applied Physics Laboratory Polar Science Center, University of Washington, Seattle, WA, USA \\ ${ }^{2}$ Department of Civil and Environmental Engineering, University of Washington, Seattle, WA, USA \\ ${ }^{3}$ Department of Earth and Space Sciences, University of Washington, Seattle, WA, USA \\ ${ }^{4}$ Department of Aerospace Engineering Sciences, University of Colorado, Boulder, CO, USA \\ ${ }^{5}$ Institute for Marine and Atmospheric research Utrecht, Utrecht University, Utrecht, the Netherlands \\ ${ }^{6}$ Geophysical Fluid Dynamics Laboratory, Princeton University, Princeton, NJ, USA \\ ${ }^{7}$ Courant Institute of Mathematical Sciences, New York University, New York, NY, USA \\ ${ }^{8}$ Center for Global Sea-Level Change, New York University, Abu Dhabi, United Arab Emirates
}

Correspondence to: David E. Shean (dshean@uw.edu)

Received: 17 December 2016 - Discussion started: 3 January 2017

Revised: 22 September 2017 - Accepted: 29 September 2017 - Published: 21 November 2017

\begin{abstract}
In the last 2 decades, Pine Island Glacier (PIG) experienced marked speedup, thinning, and grounding-line retreat, likely due to marine ice-sheet instability and ice-shelf basal melt. To better understand these processes, we combined 2008-2010 and 2012-2014 GPS records with dynamic firn model output to constrain local surface and basal mass balance for PIG. We used GPS interferometric reflectometry to precisely measure absolute surface elevation $\left(z_{\text {surf }}\right)$ and Lagrangian surface elevation change $\left(\mathrm{D} z_{\text {surf }} / \mathrm{D} t\right)$. Observed surface elevation relative to a firn layer tracer for the initial surface $\left(z_{\text {surf }}-z_{\text {surfo }}\right)$ is consistent with model estimates of surface mass balance (SMB, primarily snow accumulation). A relatively abrupt $\sim 0.2-0.3 \mathrm{~m}$ surface elevation decrease, likely due to surface melt and increased compaction rates, is observed during a period of warm atmospheric temperatures from December 2012 to January 2013. Observed $\mathrm{D} z_{\text {surf }} / \mathrm{D} t$ trends $\left(-1\right.$ to $-4 \mathrm{~m} \mathrm{yr}^{-1}$ ) for the PIG shelf sites are all highly linear. Corresponding basal melt rate estimates range from $\sim 10$ to $40 \mathrm{~m} \mathrm{yr}^{-1}$, in good agreement with those derived from ice-bottom acoustic ranging, phase-sensitive ice-penetrating radar, and high-resolution stereo digital elevation model (DEM) records. The GPS and DEM records document higher melt rates within and near features associated with longitudinal extension (i.e., transverse surface depressions, rifts). Basal melt rates for the 2012-2014 period
\end{abstract}

show limited temporal variability despite large changes in ocean temperature recorded by moorings in Pine Island Bay. Our results demonstrate the value of long-term GPS records for ice-shelf mass balance studies, with implications for the sensitivity of ice-ocean interaction at PIG.

\section{Introduction}

The widespread availability of precise Global Positioning System (GPS) measurements has revolutionized the study of ice dynamics and glacier mass balance (e.g., Gao and Liu, 2001). Continuously operating dual-frequency GPS receivers provide high-frequency ( $1 \mathrm{~Hz}$ or less), highly accurate $(<1-$ $3 \mathrm{~cm}$ ) measurements of position, which can be used to derive surface velocity and elevation change. For applications involving ice dynamics, these measurements offer important constraints for the mass continuity equation, which equates surface elevation change with ice flux divergence, surface mass balance (SMB), and basal mass balance (BMB). Here, we explore a methodology to constrain each of these components directly from GPS observables.

SMB processes include precipitation, sublimation, wind redistribution of surface snow, and meltwater runoff. Regional climate models forced by reanalysis output now pro- 
vide daily estimates of Antarctic SMB on a relatively coarse grid $(\sim 5.5$ to $27 \mathrm{~km})$. In situ SMB measurements are, however, still essential for model calibration and validation. Traditionally, SMB is measured using stake networks, automated weather stations (AWSs), near-surface radar surveys, and firn/ice cores, all of which require substantial field operations in remote locations. These measurements also tend to bias model calibration towards accessible locations, and recent studies indicate that these biases can significantly affect mass balance results, often resulting in overestimates of cumulative balance due to poor sampling in dynamic areas (Andreassen et al., 2016).

Antarctic firn/ice core records indicate that SMB variability over most of Antarctica during the last 800 years was statistically insignificant, but accumulation increased more than $10 \%$ for high-accumulation coastal regions (e.g., the Amundsen Sea Embayment) since the 1960s (Frezzotti et al., 2013). Historically, these areas have been poorly sampled with traditional methods, providing limited data available for validation of modeled SMB.

Accurate knowledge of firn compaction and its spatiotemporal variability is essential for interpreting observed surface elevation change in remote sensing data (e.g., satellite altimetry) and for partitioning this change into components related to ice dynamics and SMB (e.g., Shepherd et al., 2012; Wouters et al., 2015). Depth-dependent compaction rates can be estimated from a number of different methods, including vertical strain measurements (Arthern et al., 2010; Hamilton and Whillans, 1998), borehole optical stratigraphy (Hawley and Waddington, 2011), repeat phase-sensitive radio-echo sounding (pRES) measurements (e.g., Jenkins et al., 2006) and ice-penetrating radar observations of internal layers over time (e.g., Medley et al., 2014, 2015). In the absence of these measurements, dynamic firn models forced by modeled SMB can provide estimates of compaction rates throughout the firn column, which can be integrated to obtain estimates for the contribution of firn compaction to surface elevation change over time (e.g., Ligtenberg et al., 2011).

BMB for ice shelves (i.e., bottom melting, accretion) is driven by complex ice-ocean interaction. State-of-theart ice-shelf cavity ocean circulation models offer some insight into sub-shelf ice-ocean interaction, but these models lack validation, as in situ hydrographic observations are limited, especially within the sub-shelf cavity and the iceocean boundary layer. Some direct measurements are available from autonomous submersibles (e.g., Dutrieux et al., 2014) and instrumentation deployed through ice-shelf boreholes (e.g., Stanton et al., 2013), but available data are limited to short time periods and small spatial extents. Precise measurements of surface elevation change from remote sensing observations (e.g., laser altimetry, digital elevation models (DEMs)) can also be used to infer BMB (e.g., Dutrieux et al., 2013; Moholdt et al., 2014; Pritchard et al., 2012; Shean, 2016), but temporal resolution is limited, as time intervals between repeat observations are typically several months to years.

Here, we use continuous GPS records from the Pine Island Glacier (PIG) ice shelf to constrain local SMB, flux divergence, and BMB. We use changes in observed GPS antenna elevation and reflectometry-derived surface elevation to validate SMB and firn model output. Flux divergence is estimated from observed strain rates between GPS stations. These estimates are then used to isolate elevation change due to local BMB. This approach yields temporally dense records of basal melt rates at spatially sparse GPS locations, which are combined with high-resolution DEMs from the same time period to provide spatial context. These complementary results for the PIG ice shelf provide new information about the time-variable magnitude and spatial distribution of basal melting, offering indirect observations of ice-ocean interaction and BMB sensitivity to ocean heat content variability, with implications for other rapidly evolving "warm-cavity" Antarctic ice shelves.

\subsection{PIG background}

Pine Island Glacier is one of the largest and most dynamic ice streams in West Antarctica. Since the 1970s, PIG has experienced $\sim 30 \mathrm{~km}$ of grounding-line retreat along its centerline (Rignot et al., 2014$)(\sim 8 \mathrm{~km}$ average retreat across full width of fast-flowing trunk; Joughin et al., 2016), a $75 \%$ increase in surface velocity (Mouginot et al., 2014), and $>100 \mathrm{~m}$ of thinning (Bindschadler, 2002; Pritchard et al., 2009), with accelerated retreat beginning in the 1990s. These changes have been attributed to some combination of geometric instability (i.e., marine ice-sheet instability) and external forcing (i.e., increased ocean heat content and/or changes in sub-shelf circulation) (Jacobs et al., 2011; Joughin et al., 2010).

Present-day surface velocities are $\sim 4 \mathrm{~km} \mathrm{yr}^{-1}$, with annual discharge of 130-135 Gt (Medley et al., 2014; Mouginot et al., 2014) and net mass loss estimates of 40 to $50 \mathrm{Gt} \mathrm{yr}^{-1}$ for the full PIG catchment (Medley et al., 2014; Rignot, 2008). This mass loss is responsible for $\sim 0.11 \mathrm{~mm} \mathrm{yr}^{-1}$ global sea level rise (SLR), or approximately $40-45 \%$ of the total $\sim 0.26 \mathrm{~mm} \mathrm{yr}^{-1}$ Antarctic SLR contribution (Church et al., 2013; Rietbroek et al., 2016; Shepherd et al., 2012).

Figure 1 shows the fast-flowing portion of the PIG ice stream, which terminates in an ice shelf ("main shelf") that is $\sim 25 \mathrm{~km}$ wide, $\sim 100 \mathrm{~km}$ long, and $\sim 1-1.5 \mathrm{~km}$ thick across the grounding line. Basal melting accounts for $\sim 60-75 \%$ of mass loss from the ice shelf, with estimated 2003-2008 melt rates of $\sim 95-101 \mathrm{Gt} \mathrm{yr}^{-1}$ (Depoorter et al., 2013; Rignot et al., 2013) and 2008-2015 melt rates of $\sim 80-90 \mathrm{Gt} \mathrm{yr}^{-1}$ (Shean, 2016).

The main shelf has complex surface topography, including kilometer-scale surface ridges and troughs that correspond to basal keels and channels, respectively (Bindschadler et al., 2011; Vaughan et al., 2012). A series of longitudinal (along- 


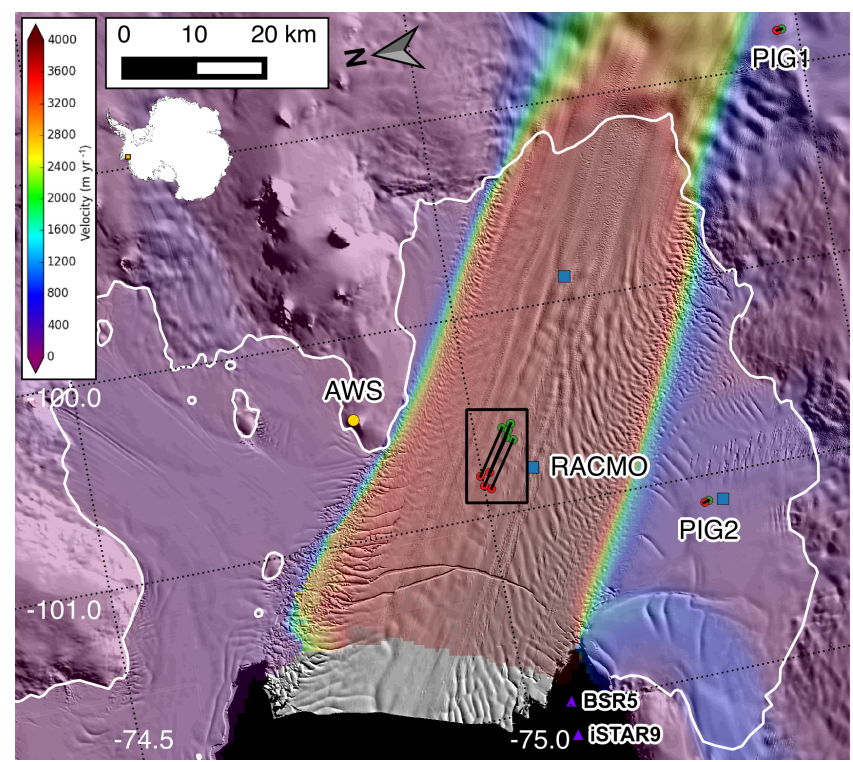

Figure 1. Context for Pine Island Glacier ice shelf with 2006-2016 median surface velocity (Christianson et al., 2016; Joughin et al., 2010) over a shaded relief map from October-December 2012 DEM mosaic. Black lines show $\sim 2$-year paths between initial (green) and final (red) GPS station locations. The yellow dot shows the Evans Knoll automated weather station (AWS) and the blue squares show RACMO grid-cell centers used during analysis. The purple triangles beyond shelf front show locations of ocean mooring temperature data from Christianson et al. (2016). The white line shows approximate 2011 grounding line (Shean, 2016). Black rectangle shows location of Fig. 2a.

flow) ridges and troughs are present along the shelf centerline, with transverse (across-flow) ridges and troughs along the lateral margins (Fig. 1). Local basal melt rates vary considerably across these features (Dutrieux et al., 2013; Shean, 2016).

Hydrographic observations seaward of the PIG calving front in Pine Island Bay suggest that basal melting declined by $\sim 50 \%$ between 2010 and 2012 (Dutrieux et al., 2014). Long-term 2009-2015 mooring records seaward of the southern calving front (Fig. 1) show a significant decrease in ocean temperature $\left(\sim 1-1.5^{\circ} \mathrm{C}\right)$ over $\sim 450-770 \mathrm{~m}$ depths from late 2011 to early 2012 and then again from mid-2012 to early 2013 (Christianson et al., 2016; Webber et al., 2017). These observations show that the ocean heat content at the PIG ice-shelf front varies considerably over monthly to interannual timescales.

\subsection{PIG GPS sites}

Several long-term GPS stations were installed on the PIG shelf as part of a larger investigation of ice-sheet, ice-shelf, and ocean dynamics (Bindschadler et al., 2011; Stanton et al., 2013). During the early part of this effort, two GPS stations continuously collected data from January 2008 to Jan- uary 2010: one on the southern PIG ice shelf (PIG2) and another on the fast-flowing, grounded ice upstream of the grounding line (PIG1) (Fig. 1). In addition, a $\sim 2 \times 2 \mathrm{~km}$ array of five stations (SOW1-4, BOAR, Fig. 2) was installed $\sim 50 \mathrm{~km}$ downstream of the grounding line, near the center of the main shelf from January 2012 to late December 2013.

The stations used dual-frequency Trimble NetRS GPS receivers (2008-2010 sites) and NetR9 receivers (2012-2014 sites), with Trimble Zephyr Geodetic 2 antennas mounted on 12 foot $(3.66 \mathrm{~m})$ poles with insulating pole-base stoppers. The poles were driven into the snow by hand, with initial pole bases set $\sim 0.5-1.0 \mathrm{~m}$ beneath the surface (M. Truffer, personal communication, 2016).

High-resolution optical imagery and DEM data (see Sect. 2.5) over the 2012-2014 sites show that SOW1, BOAR, and SOW3 were installed with along-flow orientation in a longitudinal surface trough (Fig. 2) that overlies a longitudinal basal channel. An ice-penetrating radar profile with transverse orientation was collected upstream of the GPS array, providing ice thickness estimates of $\sim 450-460 \mathrm{~m}$ near the apex of a longitudinal channel and $\sim 540 \mathrm{~m}$ over adjacent keels (Stanton et al., 2013). Figure 2 shows estimated ice thickness for longitudinal and transverse profiles across the GPS array.

A borehole was drilled through the ice shelf approximately $1.34 \mathrm{~km}$ upstream of SOW1 (K. Riverman, personal communication, 2016), and an instrument package with an upwardfacing ice-bottom altimeter (acoustic ranger) was deployed beneath the shelf from January to February 2012. Measurements from this bottom altimeter and complementary pRES experiments provided basal melt rate estimates of $\sim 14$ $25 \mathrm{~m} \mathrm{yr}^{-1}$ within the longitudinal channel (Christianson et al., 2016; Stanton et al., 2013).

The 2012-2014 GPS array was located near several transverse surface depressions (Fig. 2), which are likely associated with transverse basal channels and/or rifts. Local surface slopes were $\sim 0.6-0.9^{\circ}$ within the largest of these depressions, immediately downstream of SOW 3 and SOW4. A notable linear surface depression located approximately $1 \mathrm{~km}$ upstream of SOW1 (black arrow in Fig. 2) opened as a rift in $\sim 2014$ (R1 in Jeong et al., 2016) and was subsequently the site of a large iceberg calving event that occurred around July 2015. The placement of the 2012-2014 GPS array near these features complicates interpretation of GPS records but also provides new constraints on the spatiotemporal evolution of strain rates and rift formation for the PIG shelf.

\section{Data and methods}

\subsection{GPS antenna position}

As described in Christianson et al. (2016), GPS data were processed using differential-carrier-phase positioning relative to bedrock GPS sites - Backer Island (BACK; 

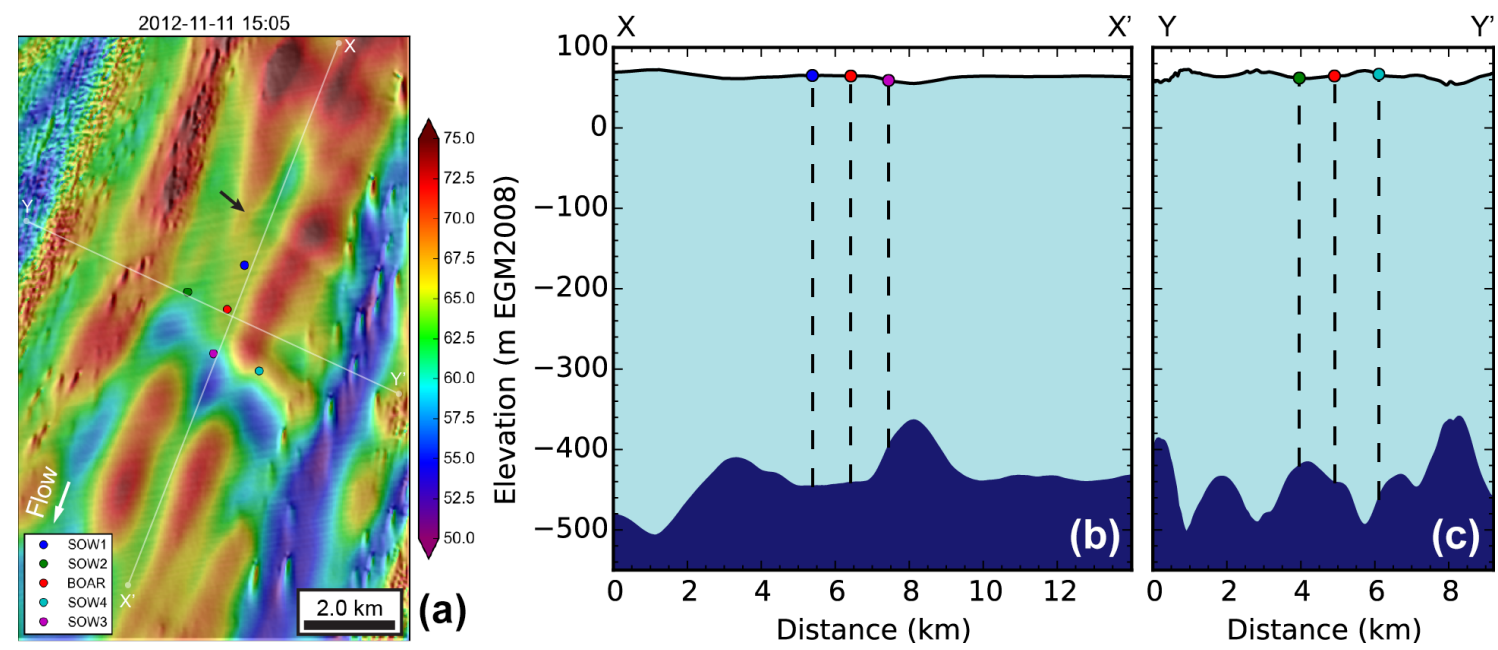

Figure 2. (a) WorldView DEM from 11 November 2012 with 2012-2014 GPS array positions overlaid. Note GPS positions relative to transverse depressions and location of R1 rift associated with 2015 calving event (black arrow). Ice-flow direction indicated by white arrow. White lines show locations of profiles. (b) Smoothed surface elevation $(0.5 \mathrm{~km}$ window, approx. $\sim 1$ ice thickness $)$ and estimated freeboard thickness for longitudinal profile $X-X^{\prime}$ and (c) transverse profile $Y-Y^{\prime}$. Profile intersection is near BOAR (red point). Vertical exaggeration is $22 \times$.

$-74.26^{\circ} \mathrm{N}, \quad-102.28^{\circ} \mathrm{E} ; \sim 60 \mathrm{~km}$ baseline) for $2012-$ 2014 records and Howard Nunatak (HOWN; $-77.31^{\circ} \mathrm{N}$, $-8.65^{\circ} \mathrm{E}$; $\sim 450 \mathrm{~km}$ baseline) for 2008-2010 records - with epoch-by-epoch zenith tropospheric delay estimation. Dailyaveraged positions of these base stations were calculated using GAMIT and stabilized relative to a fixed circumAntarctic reference frame using a Kalman filter (GLOBK; Herring et al., 2015). Antenna positions relative to the WGS84 ellipsoid were calculated every $30 \mathrm{~s}$. We analyzed a subset of these positions sampled at $10 \mathrm{~min}$ intervals and removed any positions with uncertainty $>8 \mathrm{~cm}$. The BOAR record was curtailed on 29 April 2013 (1.31-year duration), when an abrupt $\sim 2.0 \mathrm{~m}$ elevation decrease and corresponding horizontal offset occurred, suggesting that the pole fell over.

We estimate initial antenna position accuracy of $\sim 1 \mathrm{~cm}$. Positions were converted to a local Cartesian horizontal coordinate system with final antenna elevation values ( $\left.z_{\text {ant }}\right)$ as orthometric height above the EGM2008 geoid (Pavlis et al., 2012). Absolute geoid errors are poorly constrained for coastal Antarctica, but relative geoid error for the cumulative horizontal displacement of the GPS array $(\sim 8 \mathrm{~km}$ over the 2 year period) should be $<1-2 \mathrm{~cm}$. A constant offset of $3.71 \mathrm{~m}$ (3.66 $\mathrm{m}$ pole length $+0.053 \mathrm{~m}$ phase center to bottom of antenna) was removed from antenna elevation $\left(z_{\text {ant }}\right)$ to estimate corresponding pole-base elevation.

We estimated vertical tidal displacement for all GPS positions on the PIG ice shelf using CATS2008A, an updated version of the model described by Padman et al. (2002). We used mean sea level pressure values from the $0.75^{\circ}$ grid-cell ERA-Interim reanalysis products (Dee et al., 2011) to correct for vertical displacement due to the inverse barometer effect
(IBE; e.g., Padman et al., 2003). To do this, we removed the 2002-2016 median $(985.21 \mathrm{hPa})$ from $6 \mathrm{~h}$ sea level pressure and scaled the residuals by $\sim 1 \mathrm{~cm} \mathrm{hPa}^{-1}$. Figure 3 shows that tidal amplitudes for the GPS sites range from approximately -0.9 to $+1.3 \mathrm{~m}$ and IBE amplitudes range from -0.3 to $+0.3 \mathrm{~m}$. These signals were removed from the GPS antenna elevation $\left(z_{\text {ant }}\right)$, and residual high-frequency noise was removed with a low-pass filter (1.5-day cutoff), yielding smoothed time series for further analysis (Fig. 3). We conservatively estimate final $z_{\text {ant }}$ absolute accuracy of $\sim 0.1 \mathrm{~m}$.

\subsection{Antenna-surface distance}

The GPS interferometric reflectometry (GPS-IR) method provides a precise measurement of antenna phase-center height above a reflecting surface (Larson, 2016). The reflecting surface for PIG is the interface between the atmosphere and the snow/firn surface, and we define the antenna height above this interface as the "antenna-surface distance" $\left(h_{\text {ant-surf }}\right)$. Figure 4 shows a schematic of this GPS site geometry.

Assuming that the GPS pole base remains fixed within its original firn layer (see Sect. 5.3 for further discussion), observed decreases in the antenna-surface distance ( $\left.h_{\text {ant-surf }}\right)$ can be attributed to surface accumulation (e.g., snowfall, deposition of snow by wind). Conversely, an increase in antenna-surface distance can be attributed to surface ablation (e.g., melt, sublimation, removal of snow by wind) and compaction of snow and/or firn above the pole base.

We computed mean daily antenna-surface distance for all sites using L1 C/A code multipath surface reflections and the GPS interferometric reflectometry methodology outlined in 


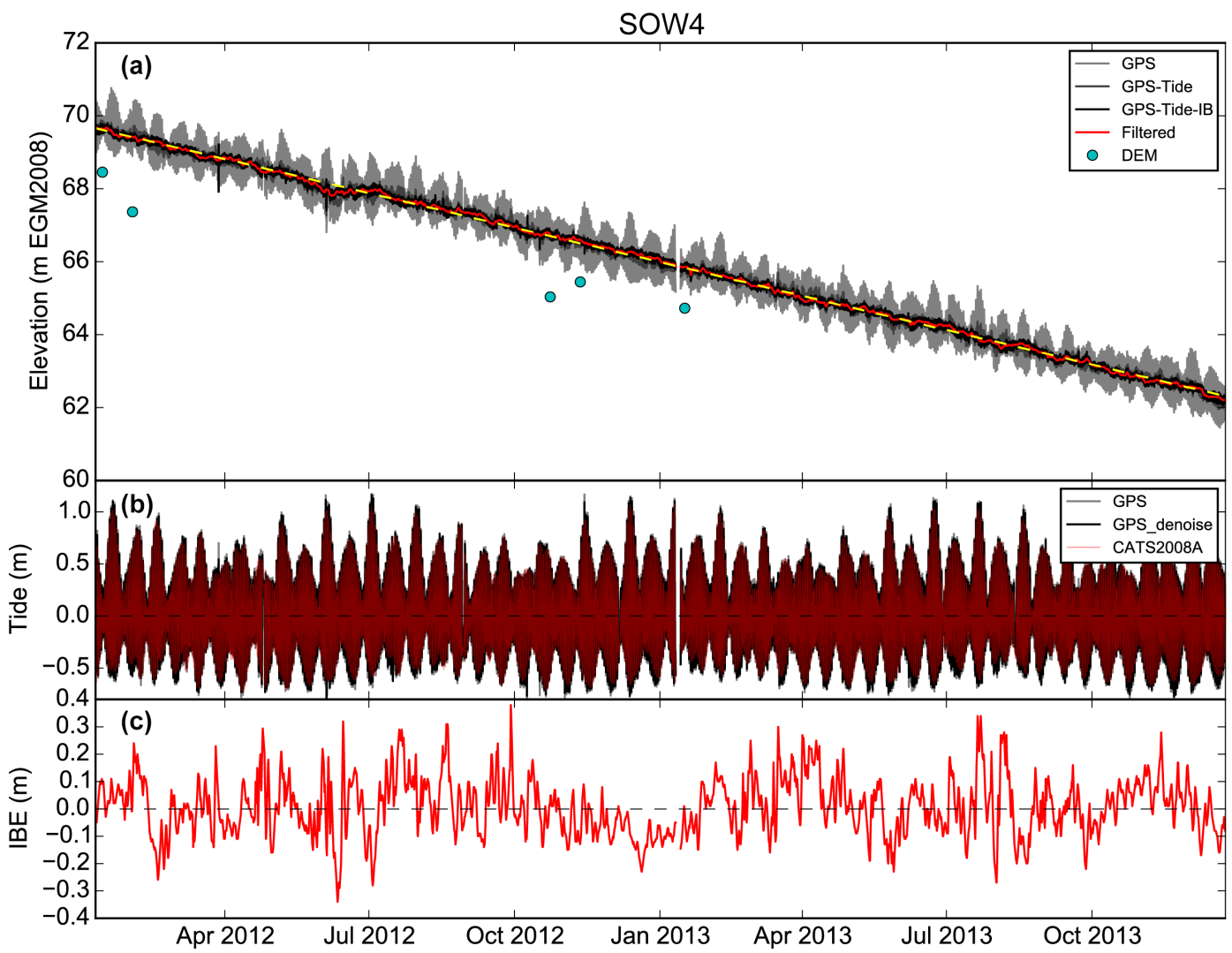

Figure 3. (a) Original GPS antenna elevation (light gray), after tide correction (mid-gray), and after tide+IBE correction (black) for SOW4. The red line shows smoothed time series and the yellow dashed line is linear fit $\left(-3.76 \mathrm{~m} \mathrm{yr}^{-1}\right)$. Sampled DEM elevations (cyan) show surface elevation, which is offset from GPS antenna elevation by antenna-surface distance (see Figs. 4 and 8 ). (b) High-frequency ( $<1.5$ days) component of GPS record and CATS2008A tide model prediction, showing excellent agreement. (c) Estimated inverse barometer effect (IBE) magnitude from scaled sea level pressure.

Larson et al. (2015). This method takes advantage of the fact that the interference between the direct and reflected GPS signals produces characteristic frequencies in signal-to-noise ratio data recorded by the GPS receiver; these frequencies are directly related to the distance between the GPS antenna phase center and the reflecting surface. Geodetic antennas are designed to suppress multipath, so these interference patterns are best resolved at low GPS satellite elevation angles. Reflector height solutions were calculated for elevation angles of $5-25^{\circ}$, which sample the surface within a radial extent of $\sim 5-50 \mathrm{~m}$. Local surface slopes at each site are negligible, eliminating the need for an azimuthal correction (e.g., Larson and Nievinski, 2013). Daily antenna-surface distance ( $h_{\text {ant-surf }}$ ) accuracy is estimated to be $\sim 1 \mathrm{~cm}$ (Larson et al., 2015).

\subsection{GPS-derived surface elevation}

The antenna-surface distance ( $\left.h_{\text {ant-surf }}\right)$ was subtracted from antenna elevation $\left(z_{\text {ant }}\right)$ to obtain daily records of surface elevation $z_{\text {surf }}$ (i.e., elevation of the air-snow interface above the EGM2008 geoid), with resulting relative accuracy of $\sim 1-$
$2 \mathrm{~cm}$ (absolute accuracy subject to the same $\sim 0.1 \mathrm{~m} z_{\text {ant }}$ uncertainty due to tidal, IBE, and geoid corrections). The $z_{\text {surf }}$ surface elevation values are directly comparable with satellite or airborne laser altimetry data and stereo DEM products. We use variable name $z_{\text {surf }}$ rather than the more traditional glaciological variable name $h$ to limit potential confusion between different "height" and "elevation" variables.

Continuous $z_{\text {surf }}$ time series were generated for all seven PIG GPS sites. The SOW3 record was curtailed on $22 \mathrm{Au}-$ gust 2013, when antenna-surface distance decreased below the minimum threshold of $\sim 0.5 \mathrm{~m}$ (Nievinski, 2013).

\subsection{GPS velocity and strain rate}

Horizontal velocities for each GPS station were computed from daily mean antenna positions. We calculated principal strain rates for eight different triangular sections within the array (each defined by unique combination of three sites), using the methods outlined by Savage et al. (2001). We tested multiple time intervals for these strain rate calculations, from 2 to 120 days, and use 42 days as a compromise between temporal resolution and uncertainty (assuming uncorrelated 


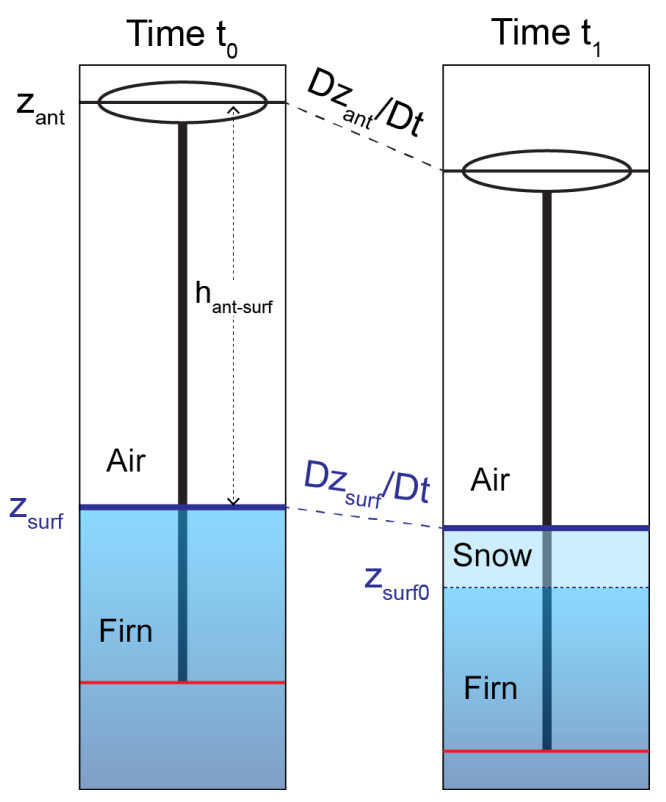

Figure 4. Schematic of GPS station geometry. Surface elevation ( $z_{\text {surf }}$, dark blue line) is computed by removing antenna-surface distance ( $h_{\text {ant-surf }}$, dotted black line) from antenna elevation ( $z_{\text {ant }}$, black line). Pole-base elevation (red line) is computed from pole length and antenna phase-center offset. At time $t_{1}$ (right panel), ongoing firn compaction resulted in decreased antenna and pole-base elevation, while new snow accumulation offset surface lowering. The layer within the firn column corresponding to the initial surface $\left(z_{\text {surf } 0}\right)$ is represented by dotted blue line.

daily position error of $\sim 1 \mathrm{~cm}$ ). We used observed horizontal strain rates to estimate elevation change related to local flux divergence.

Some component of observed GPS surface elevation change may also be related to deformation due to local gradients in the driving stress and surface-parallel flow due to advection over basal topography. The vertical component of surface-parallel flow ( $V_{0}$ in Larson et al., 2015) can be estimated using observed horizontal GPS paths and surface gradients from an independent DEM. Advection over bed topography is irrelevant for a freely floating ice shelf, and we attempt to estimate an upper bound for $V_{0}$ due to local deformation by considering local surface gradients and observed relative horizontal displacements within the 2012-2014 GPS array.

\subsection{High-resolution DEMs}

In addition to the GPS elevation data, we generated WorldView/GeoEye stereo DEMs (Shean et al., 2016) with $32 \mathrm{~m}$ posting over the PIG shelf (Shean, 2016) to provide spatial context for the GPS time series. A total of seven WorldView DEMs intersected the 2012-2014 GPS positions. We sampled DEM surface elevation at corresponding GPS po- sitions and compared with GPS-derived surface elevation where possible.

High-resolution Lagrangian $\mathrm{D} z_{\text {surf }} / \mathrm{D} t$ maps (see methodology in Shean, 2016; note we use $\mathrm{D} / \mathrm{D} t$ to indicate a Lagrangian differential operator) were computed for the 2012 2014 GPS sites by forward-propagating $32 \mathrm{~m}$ DEM pixels from two initial DEM products (2 February 2012 and 23 October 2012) using interpolated, time-variable surface velocity maps from Joughin et al. (2010) and Christianson et al. (2016). Lagrangian $\mathrm{D} z_{\text {surf }} / \mathrm{D} t$ maps were generated for all valid combinations of these initial DEMs and $\sim 15$ subsequent DEMs $(\sim 0.5-2.5$ years later). Composite products were generated, with median $\mathrm{D} z_{\text {surf }} / \mathrm{D} t$ values assigned to initial DEM pixel locations.

\subsection{Surface mass balance}

We analyzed estimates of 1979-2015 monthly and 20102013 daily SMB for three $27 \mathrm{~km}$ grid cells over the PIG shelf from the Regional Atmospheric Climate Model (RACMO) v2.3 (Ettema et al., 2009; Lenaerts et al., 2012; Van Meijgaard et al., 2008; Van Wessem et al., 2014). The average 1979-2015 SMB $(\bar{a})$ is $0.91 \mathrm{mw}$ we. $\mathrm{yr}^{-1}$ for the grid cell closest to the $2012-2014$ GPS array $\left(-75.07^{\circ} \mathrm{N}\right.$, $-100.80^{\circ} \mathrm{E}$, Fig. 1). The values for adjacent grid cells are $0.74 \mathrm{~m}$ w.e. $\mathrm{yr}^{-1}$ near the grounding line of the main shelf $\left(-75.15^{\circ} \mathrm{N},-99.88^{\circ} \mathrm{E}\right)$ and $0.84 \mathrm{~m}$ w.e. $\mathrm{yr}^{-1}$ over the south shelf $\left(-75.30^{\circ} \mathrm{N},-101.14^{\circ} \mathrm{E}\right)$, providing some information on large-scale spatial variability. These values are consistent with SMB estimates of $\sim 0.5-1.0 \mathrm{~m}$ w.e. $\mathrm{yr}^{-1}$ derived from CReSIS snow radar data collected upstream of the PIG grounding line (Medley et al., 2014, 2015) and SMB esti-

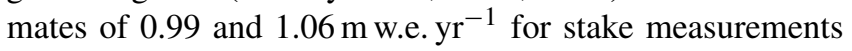
near 2006-2008 GPS sites over the upstream PIG trunk (Scott et al., 2009). We conservatively estimate SMB uncertainty of $0.2 \mathrm{~m}$ w.e. $\mathrm{yr}^{-1}$.

\subsection{AWS temperature data}

To provide context for surface elevation change due to surface melt events, we analyzed continuous 2011-2015 temperature data ( $3 \mathrm{~h}$ interval) from the Evans Knoll AWS $\left(-74.85^{\circ} \mathrm{N},-100.40^{\circ} \mathrm{E}\right.$; Lazzara et al., 2012), located at an elevation of $\sim 178 \mathrm{~m}$ (height above EGM2008 geoid) on a bedrock outcrop approximately $40 \mathrm{~km}$ north of the 2012 2014 GPS array (Fig. 1). We also analyzed New York University (NYU) AWS temperature data available near PIG2 from 9 January 2008 to 7 November 2009 and near BOAR from 19 January 2013 to 26 May 2015. Unfortunately, no AWS data were collected on the PIG shelf during 2012. An analysis of overlapping time periods for the Evans Knoll and 2013-2015 NYU AWS temperature records shows a median offset of $+1.24^{\circ} \mathrm{C}$ (Evans Knoll warmer than NYU, with normalized median absolute deviation (NMAD) of $2.76^{\circ} \mathrm{C}$ ), which is consistent with a dry adiabatic lapse rate and lo- 
cal site conditions. This offset was removed from the Evans Knoll temperature data to provide a continuous temperature estimate for the GPS sites over the full 2012-2014 period.

To provide historical context, we extracted $2 \mathrm{~m}$ air temperature over the PIG shelf from $0.75^{\circ}$-resolution ERA-Interim reanalysis products (Dee et al., 2011) for the 1979-2015 period with $6 \mathrm{~h}$ interval. The median offset between the ERAInterim temperature data and the 2013-2015 NYU AWS temperature data was $+0.10^{\circ} \mathrm{C}$ (ERA-Interim warmer than NYU) with NMAD $2.78^{\circ} \mathrm{C}$. This median offset was removed from the ERA-Interim temperatures. We did not attempt to correct any seasonal bias in ERA-Interim products (e.g., Jones et al., 2016).

\subsection{Firn model}

We used a dynamic firn model to simulate elevation change related to SMB and firn processes. Model SMB output from RACMO2.3 (Sect. 2.6) was used to force the semi-empirical 1-D IMAU-FDM dynamic firn model (Ligtenberg et al., 2011) with $3 \mathrm{~h}$ timestep, and IMAU-FDM output was generated at 2-day intervals. Velocity $\left(v_{\text {ice }}\right)$ across the firn-ice transition (defined as the layer with $917 \mathrm{~kg} \mathrm{~m}^{-3}$ density) was assumed to be in equilibrium with average 1979-2015 SMB $\left(\bar{a}=0.91 \mathrm{~m}\right.$ w.e. $\left.\mathrm{yr}^{-1}\right)$, so that $v_{\text {ice }}=\bar{a} / \rho_{\mathrm{i}}$. Vertical velocity components for surface accumulation, surface sublimation, surface snow drift erosion/deposition, surface melt, dry firn compaction, and a vertical buoyancy correction (over floating ice-shelf grid cells) were computed for the 2008-2010 and 2012-2014 periods (see Ligtenberg et al., 2011, for model details). These components were combined to provide time series of simulated surface elevation $\left(\widetilde{z_{\text {surf }}}\right)$ at each GPS station. In addition, simulated elevations were computed over time for tracers corresponding to the initial surface and pole base. We conservatively estimate IMAU-FDM surface elevation uncertainty of $\sim 10 \%$, which corresponds to $\sim 0.05 \mathrm{~m}$ for $\widetilde{z_{\text {surf }}}$.

\section{Derivation of basal mass balance}

We combine the above observations and model output to estimate basal mass balance for the PIG GPS sites. Mass conservation for a column with ice-equivalent thickness $H_{\text {ice }}$ (after removing a thickness correction $d$ that accounts for total air content in the firn column) relates Eulerian thickness change ( $\mathrm{d} H_{\text {ice }} / \mathrm{d} t$ ) with dynamic thinning or thickening due to flux divergence $\left(\nabla \cdot H_{\text {ice }} \boldsymbol{u}\right.$, positive for extension), surface mass balance $\dot{a}$ (meters ice equivalent), and basal mass balance $\dot{b}$ (meters ice equivalent, defined as positive for melt):

$\frac{\partial H_{\text {ice }}}{\partial t}=-\nabla \cdot\left(H_{\text {ice }} \boldsymbol{u}\right)+\dot{a}-\dot{b}$.

The material derivative definition relates Eulerian (fixed reference frame) and Lagrangian (reference frame moving with the ice column) thickness change:

$\frac{\mathrm{D} H_{\text {ice }}}{\mathrm{D} t}=\frac{\partial H_{\text {ice }}}{\partial t}+\boldsymbol{u} \cdot\left(\nabla H_{\text {ice }}\right)$.

Rearranging Eq. (2) and substituting into Eq. (1), we obtain the mass conservation equation for Lagrangian thickness change:

$\frac{\mathrm{D} H_{\text {ice }}}{\mathrm{D} t}=-H_{\mathrm{ice}}(\nabla \cdot \boldsymbol{u})+\dot{a}-\dot{b}$.

For a floating ice shelf in hydrostatic equilibrium, we can estimate ice-equivalent thickness from air-column-corrected surface elevation $\left(z_{\text {surf }}-d\right)$, where $z_{\text {surf }}$ is measured surface elevation and $d$ is total firn-air content:

$H_{\text {ice }}=\left(z_{\text {surf }}-d\right)\left(\frac{\rho_{\mathrm{w}}}{\rho_{\mathrm{w}}-\rho_{\mathrm{i}}}\right)$,

assuming a constant bulk density for ocean water $\left(\rho_{\mathrm{w}}=\right.$ $\left.1026 \pm 1 \mathrm{~kg} \mathrm{~m}^{-3}\right)$ and ice $\left(\rho_{\mathrm{i}}=917 \pm 5 \mathrm{~kg} \mathrm{~m}^{-3}\right)$. We substitute Eq. (4) into (3) and rearrange to estimate basal melt rate from observed surface elevation change:

$\dot{b}=-\left(\frac{\mathrm{D} z_{\text {surf }}}{\mathrm{D} t}+\left(z_{\text {surf }}-d\right)(\nabla \cdot \boldsymbol{u})\right)\left(\frac{\rho_{\mathrm{w}}}{\rho_{\mathrm{w}}-\rho_{\mathrm{i}}}\right)+\dot{a}$.

Here, we assume that the total firn-air content remains constant for the period $\mathrm{d} t$ and drop the constant $d$ from the material derivative term $(d \approx 12 \mathrm{~m}$ for the PIG shelf, with uncertainty of $\sim 2 \mathrm{~m}$; see Appendix in Shean, 2016). This simplification is supported by the limited temporal variability $( \pm 0.3 \mathrm{~m}$, or $\sim 1-3 \%)$ in modeled IMAU-FDM total firn air content for the three PIG shelf grid cells during the relevant $\sim 2$-year study periods.

The effects of processes that drive short-term surfaceelevation change (e.g., accumulation, melting) are largely absent below the upper few meters of the firn column. Thus, elevation change at the GPS pole base (equivalent to $\mathrm{D} z_{\text {ant }} / \mathrm{D} t$ for constant pole length) displays less variability than elevation change at the surface, as it is most sensitive to (1) compaction rates within the underlying firn, (2) the long-term average SMB (see Sect. 2.8), (3) BMB, and (4) flux divergence. For the pole-base depths and time periods involved in this study, the first two terms display limited to no variability, the flux divergence term is negligible, and observed $\mathrm{D} z_{\text {ant }} / \mathrm{D} t$ can capture basal melt rate variability that might be obscured by surface accumulation and ablation signals in observed $\mathrm{D} z_{\text {surf }} / \mathrm{D} t$.

\section{Results}

\subsection{Horizontal velocity}

Figure 5a shows horizontal surface velocities of the PIG1 and PIG2 stations. On the floating ice at PIG2, velocity increased from $\sim 355$ to $\sim 380 \mathrm{~m} \mathrm{yr}^{-1}$ between 2008 and 2010 

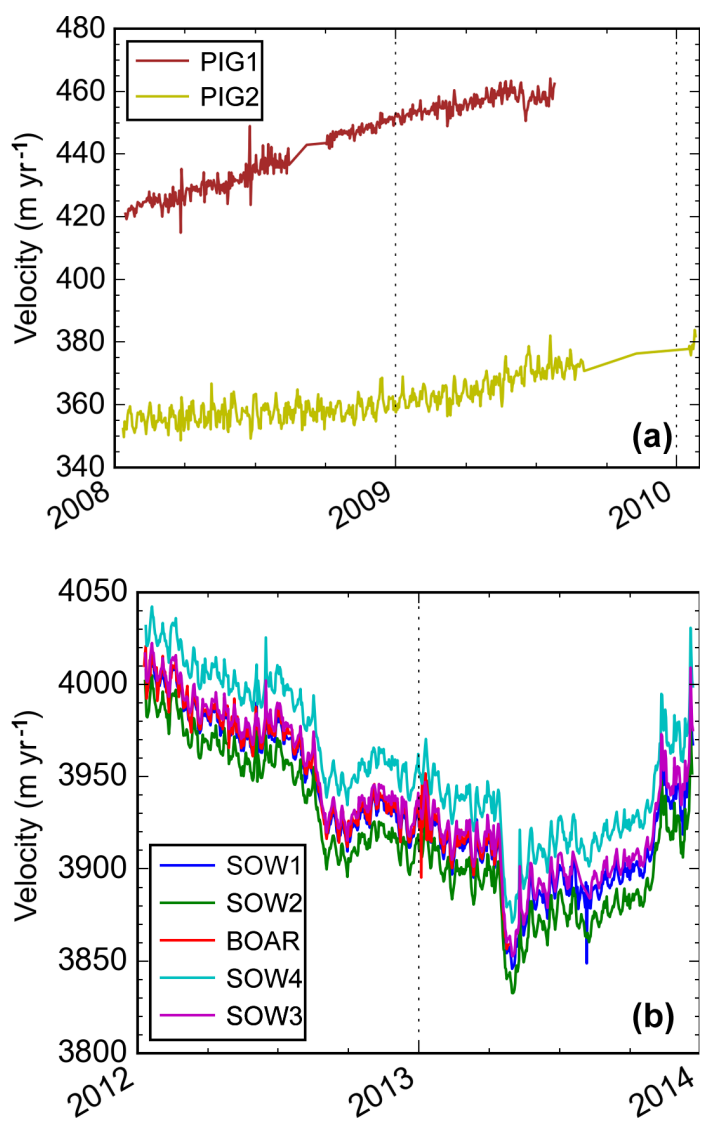

Figure 5. Station velocities derived from daily mean positions for (a) 2008-2010 GPS sites and (b) 2012-2014 GPS sites. Note offset between SOW2 and SOW4, indicative of lateral shear across the $\sim 2 \mathrm{~km}$ wide array, with greater extension near the center of the PIG shelf.

as the GPS moved downstream. Velocities for grounded ice at PIG1 increased at a relatively steady rate from $\sim 420$ to $\sim 460 \mathrm{~m} \mathrm{yr}^{-1}$ as the station moved toward the fast-flowing PIG trunk (Fig. 1).

Figure 5b shows the 2012-2014 velocities for the GPS array, which varied from $\sim 3830$ to $4040 \mathrm{~m} \mathrm{yr}^{-1}$ (Christianson et al., 2016). Velocities at SOW1, BOAR, and SOW3 were similar, while SOW4 (closer to shelf centerline) consistently moved $\sim 20 \mathrm{~m} \mathrm{yr}^{-1}$ faster than these three sites, and SOW2 consistently moved $\sim 15 \mathrm{~m} \mathrm{yr}^{-1}$ slower. Thus, there appears to be $\sim 30-40 \mathrm{~m} \mathrm{yr}^{-1}$ dextral (right-handed) shear across the $\sim 2.4 \mathrm{~km}$ distance between the SOW4 and SOW2 sites. This transverse velocity gradient is also apparent in velocity mosaics (e.g., Christianson et al., 2016).

The velocity of all five stations varied by $\sim 2-4 \%$ from 2012 to 2014, as described in detail by Christianson et al. (2016). In general, the stations displayed similar relative velocity evolution, with several abrupt $>0.1-0.2 \mathrm{mday}^{-1}$ velocity changes during the $\sim 2$-year period (Fig. 5).

\subsection{Strain rate}

Figure 6 shows strain rate magnitude and direction for 8 different strain triangles within the 2012-2014 GPS array. Mean principal strain rates were $+0.0018 \mathrm{yr}^{-1}$ (extension approximately in the along-flow direction) and $-0.0001 \mathrm{yr}^{-1}$ (compression approximately in the across-flow/transverse direction). The array displayed a clockwise rotation rate of $\sim 1^{\circ} \mathrm{yr}^{-1}$.

Spatial variations of strain rates within the array are small (Fig. 6). Strain triangles including SOW1 experienced higher strain rates, while triangles including SOW3 experienced lower strain rates, despite its location within the large transverse depression (Fig. 2). Strain rate temporal variability is also limited, but there do appear to be significant changes correlated with shelf-wide velocity changes. In general, increased (decreased) extensional strain rates were observed following an increase (decrease) in absolute GPS array velocity.

Local surface slopes near SOW1, SOW2, and BOAR are negligible $\left(<0.2^{\circ}\right)$, so we assume no surface-parallel vertical motion for these stations (i.e., $V_{0}=0$ ). If all of the observed $\sim 3.4 \mathrm{~m} \mathrm{yr}^{-1}$ relative displacement between SOW1 and SOW3 was attributed to flow down $\sim 0.6^{\circ}$ local surface slopes at SOW3, then the associated $\mathrm{V}_{0}$ magnitude would only be $\sim 0.03 \mathrm{~m} \mathrm{yr}^{-1}$, which is negligible compared to the observed $\sim 5.2 \mathrm{~m} \mathrm{yr}^{-1} \mathrm{D}_{\text {surf }} / \mathrm{D} t$.

For estimated ice-equivalent thickness of $\sim 430-500 \mathrm{~m}$, the observed strain rates correspond to shelf thinning rates $\left(\mathrm{D} H_{\text {ice }} / \mathrm{D} t\right)$ of $\sim 0.5-0.9 \mathrm{~m} \mathrm{yr}^{-1}$, with expected surface elevation change $\left(\mathrm{D} z_{\text {surf }} / \mathrm{D} t\right)$ of only $\sim 0.07-0.13 \mathrm{~m} \mathrm{yr}^{-1}$. Based on these estimates, we assume a value of $-0.1 \pm$ $0.03 \mathrm{~m} \mathrm{yr}^{-1}$ for the divergence term in Eq. (5).

\subsection{Antenna-surface distance}

Initial antenna-surface distances ( $\left.h_{\text {ant-surf }}\right)$ were $\sim 2.5$ to $3.1 \mathrm{~m}$, indicating that initial pole-base depths were $\sim 0.6$ to $1.2 \mathrm{~m}$ below the initial surface (Figs. 7a, 8). Antenna-surface distance decreased over time at all sites, with $\mathrm{D} h_{\text {ant-surf }} / \mathrm{D} t$ rates of approximately -0.8 to $-1.1 \mathrm{~m} \mathrm{yr}^{-1}$ (Fig. $7 \mathrm{a}$ ).

At both PIG1 and PIG2, there were periods of relatively rapid antenna-surface distance decrease (e.g., from May to August 2008), followed by a steady increase (e.g., August 2008 to February 2009). These changes are consistent with periods of snow accumulation followed by several months of ongoing firn compaction with limited snowfall. The 2012-2014 records show similar periods of abrupt antenna-surface distance decrease and steady increase, with more limited duration.

All GPS array records show an abrupt antenna-surface distance increase $(\sim 0.2-0.3 \mathrm{~m})$ between December 2012 and January 2013, which is consistent with surface melting and/or enhanced firn-compaction rates above the pole base (i.e., upper few meters of the firn column). 

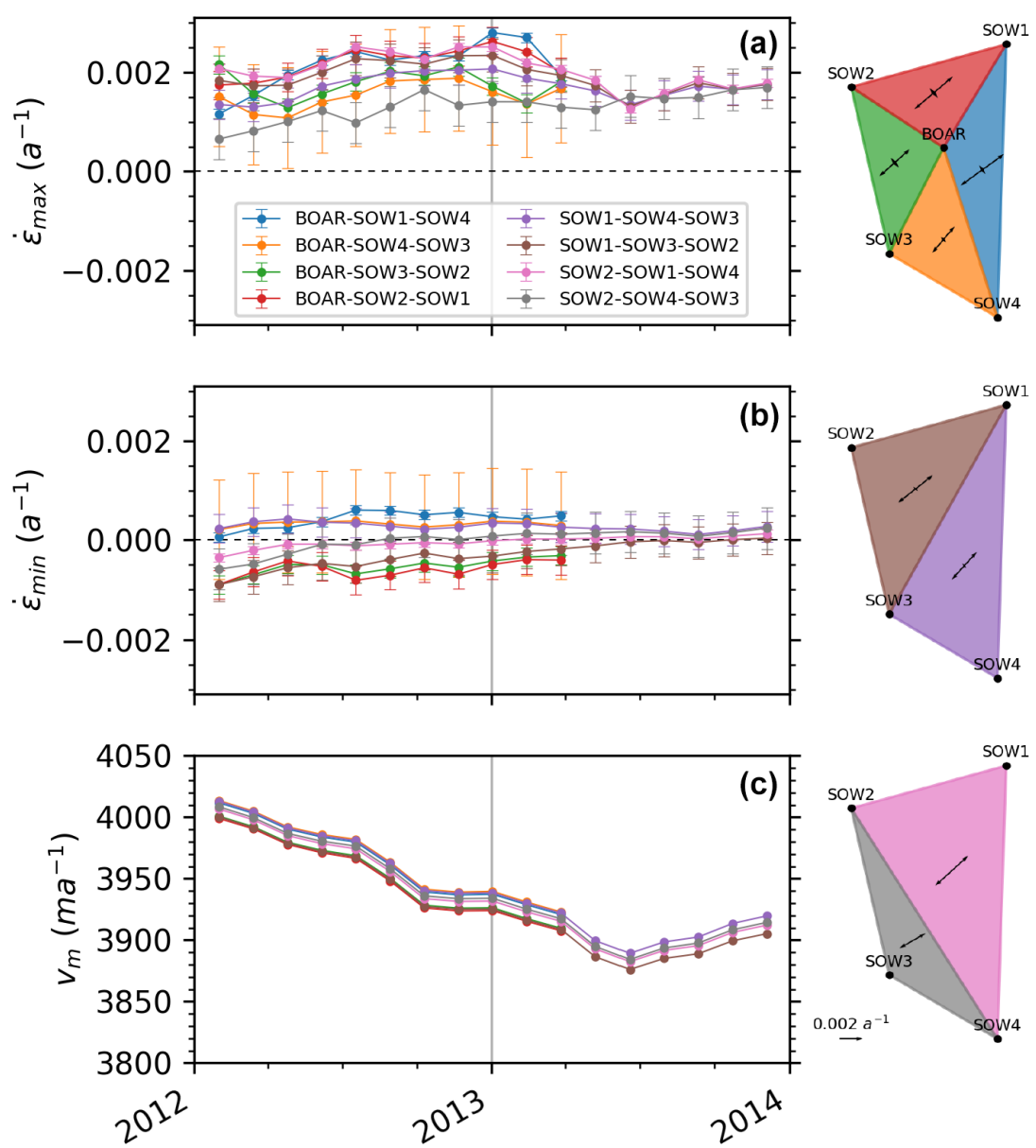

Figure 6. Horizontal strain rates over 42-day periods for eight different triangular sections within the GPS array. (a) First principal strain rate, positive for extension. Error bars calculated for uncorrelated GPS position error of $1 \mathrm{~cm}$. (b) Second principal strain rate. (c) Velocity magnitude. Diagrams in right column show color-coded triangular sections, with $\sim 2$-year mean of principal strain rates plotted at centroids.

\subsection{GPS antenna and surface elevation change}

Trends in observed antenna elevation change $\left(\mathrm{D} z_{\text {ant }} / \mathrm{D} t\right)$ are negative and highly linear $\left(R^{2} 0.98-1.00\right)$ for all PIG shelf sites, with rates of -1.6 to $-2.1 \mathrm{~m} \mathrm{yr}^{-1}$ at SOW1, SOW2, and BOAR and higher rates of -5.2 and $-3.8 \mathrm{~m} \mathrm{yr}^{-1}$ at SOW3 and SOW4, respectively (Fig. 7b, Table 1). Observed $\mathrm{D} z$ ant $/ \mathrm{D} t$ over grounded ice at PIG1 is $-7.6 \mathrm{~m} \mathrm{yr}^{-1}$, with apparent concave-downward curvature. This is consistent with $V_{0}$ expected for surface-parallel flow (see Sect. 2.4) and dynamic thinning over the PIG trunk associated with velocity increases in 2006-2008 GPS observations (Scott et al., 2009) and satellite records (Joughin et al., 2010; Mouginot et al., 2014).

The 2008-2010 surface elevation change $\left(\mathrm{D} z_{\text {surf }} / \mathrm{D} t\right)$ at PIG2 is limited $\left(-0.13 \mathrm{~m} \mathrm{yr}^{-1}\right)$. By contrast, surface elevations decreased significantly at all 2012-2014 GPS array sites, with rates of -0.9 to $-1.3 \mathrm{~m} \mathrm{yr}^{-1}$ for SOW1, SOW2, and BOAR and rates of -4.1 and $-3.0 \mathrm{~m} \mathrm{yr}^{-1}$ at SOW 3 and SOW4, respectively.
Residuals about these linear fits (Fig. 9a and b) are small for PIG shelf sites (root mean square error (RMSE) of $0.095 \mathrm{~m}$ for $\mathrm{D} z_{\text {ant }} / \mathrm{D} t$, and RMSE of $0.143 \mathrm{~m}$ for $\mathrm{D} z_{\text {surf }} / \mathrm{D} t$ ), with some seasonal to annual variability. We also note relatively abrupt ( $\sim$ days-weeks) elevation changes that occurred across all stations in the 2012-2014 array (e.g., -0.3 to $+0.3 \mathrm{~m}$ anomaly during June 2012 ).

\subsection{Surface mass balance}

We consider surface elevation $\left(z_{\text {surf }}\right)$ relative to a firn layer tracer for the initial surface elevation $\left(z_{\text {surfo }}{ }^{\prime}\right)$ to estimate cumulative elevation change due to SMB after GPS installation. Observed $z_{\text {surf }}-z_{\text {surfo }}$ rates were $\sim 0.9-1.1 \mathrm{~m} \mathrm{yr}^{-1}$ for 2008 2010 sites and $\sim 0.8-0.9 \mathrm{~m} \mathrm{yr}^{-1}$ for 2012-2014 sites (with SOW3 at $\sim 1.1 \mathrm{~m} \mathrm{yr}^{-1}$ ) (Fig. 9c).

The average RACMO SMB over the central PIG shelf from 1979 to 2015 is $\sim 0.9$ mw.e. $\mathrm{yr}^{-1}$. Monthly SMB climatology shows low accumulation rates of $\sim 0.01$ $0.04 \mathrm{~m}$ w.e. month $^{-1}$ over the PIG shelf during the austral 


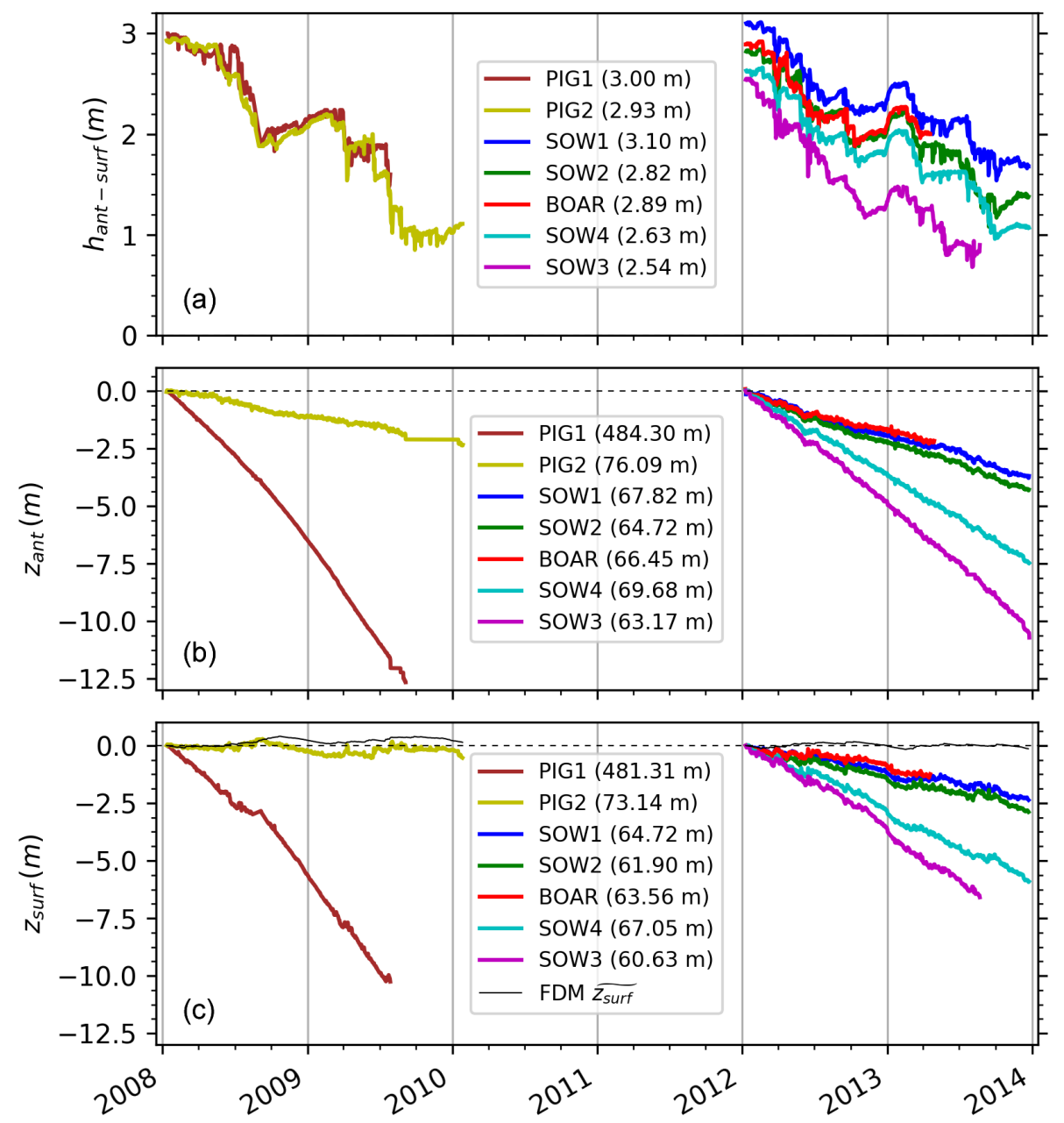

Figure 7. (a) Observed antenna-surface distance ( $h_{\text {ant-surf }}$ ) for each station. Legend lists original distance. (b) Observed antenna elevation $\left(z_{\text {ant }}\right)$ relative to initial absolute antenna elevation values listed in legend. (c) Calculated surface elevation $\left(z_{\text {surf }}\right)$ and simulated IMAU-FDM surface elevation from SMB/firn $\left(\widetilde{z_{\text {surf }}}\right.$, thin black lines $)$, both relative to initial absolute surface elevation values listed in legend.
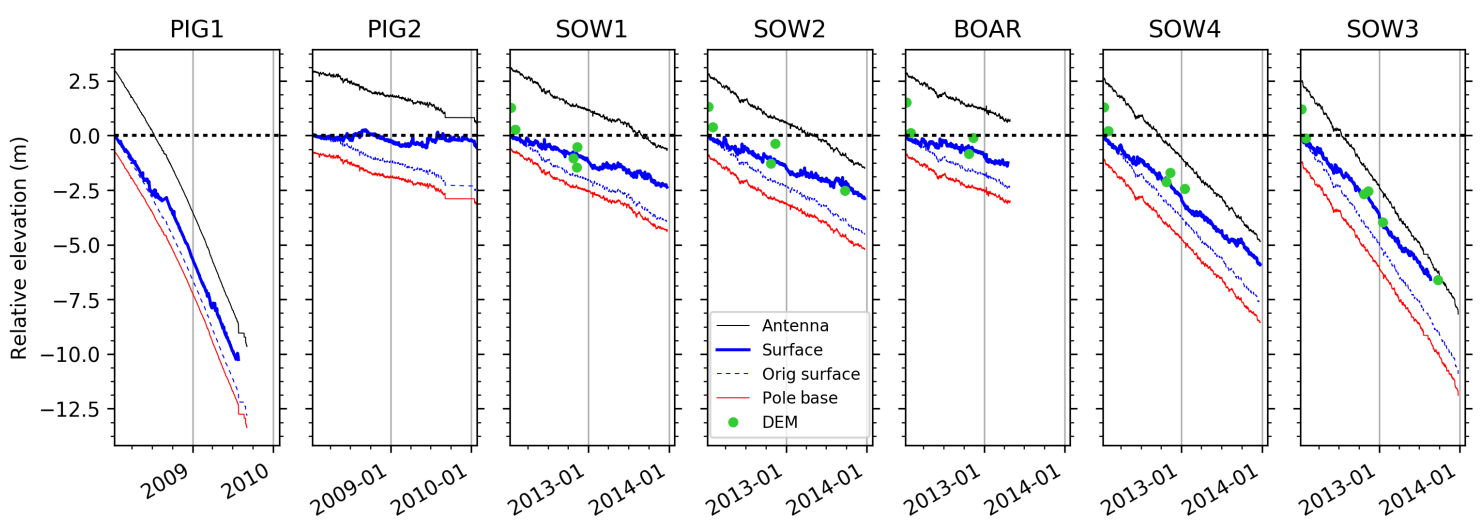

Figure 8. Time series of GPS antenna elevation (black), surface elevation (thick blue), tracer for initial surface (dotted blue), and pole-base elevation (red), all relative to initial absolute surface elevation. See schematic in Fig. 4. Green points show sampled WorldView DEM surface elevation. Note surface elevation decrease at all sites but PIG2. 
Table 1. GPS station data. Fields include surface elevation change relative to tracer for initial surface $\mathrm{D}\left(z_{\text {surf }}-z_{\text {surfo }}{ }^{\prime}\right) / \mathrm{D} t$, antenna elevation change $\mathrm{D} z_{\text {ant }} / \mathrm{D} t$ (equal to pole-base elevation change), surface elevation change $\mathrm{D} z_{\text {surf }} / \mathrm{D} t$, and corresponding ice-equivalent basal melt rate $\dot{b}$. ${ }^{*}$ PIG1 values over grounded ice do not include correction to remove expected $\mathrm{D} z_{\text {surf }} / \mathrm{D} t$ due to advection along local surface slopes $\left(V_{0}\right)$.

\begin{tabular}{lllccccc}
\hline Site & Start date & End date & Days & $\begin{array}{c}\mathrm{D}\left(z_{\text {surf }}-z_{\text {surfo }}\right) / \mathrm{D} t \\
\left(\mathrm{~m} \mathrm{yr}^{-1}\right)\end{array}$ & $\begin{array}{c}\mathrm{D} z_{\text {ant }} / \mathrm{D} t \\
\left(\mathrm{~m} \mathrm{yr}^{-1}\right)\end{array}$ & $\begin{array}{c}\mathrm{D} z_{\text {surf }} / \mathrm{D} t \\
\left(\mathrm{~m} \mathrm{yr}^{-1}\right)\end{array}$ & $\begin{array}{c}\dot{b} \\
\left(\mathrm{~m} \mathrm{yr}^{-1}\right)\end{array}$ \\
\hline PIG1 & $2008-1-13$ & $2009-9-4$ & 601 & 0.93 & $-7.60^{*}$ & $-6.76^{*}$ & - \\
PIG2 & $2008-1-10$ & $2010-1-27$ & 747 & 1.12 & -1.12 & -0.13 & $2.0 \pm 0.9$ \\
SOW1 & $2012-2-10$ & $2013-12-23$ & 714 & 0.77 & -1.81 & -1.13 & $11.5 \pm 1.1$ \\
SOW2 & $2012-2-10$ & $2013-12-23$ & 714 & 0.85 & -2.08 & -1.33 & $13.3 \pm 1.2$ \\
BOAR & $2012-2-10$ & $2013-4-29$ & 476 & 0.78 & -1.58 & -0.91 & $9.4 \pm 1.1$ \\
SOW4 & $2012-2-10$ & $2013-12-24$ & 714 & 0.86 & -3.76 & -3.00 & $29.1 \pm 1.7$ \\
SOW3 & $2012-2-9$ & $2013-12-24$ & 716 & 1.10 & -5.23 & -4.10 & $39.4 \pm 2.1$ \\
\hline
\end{tabular}

summer (November to February) and high accumulation rates of $\sim 0.08-0.10 \mathrm{~m}$ w.e. month $^{-1}$ during austral winter (March to October) (Fig. 9d). Daily SMB products show periods of days to weeks with increased accumulation (e.g., March 2013) that can be correlated with abrupt decreases in antenna-surface distance.

The $\sim 3-4$-week period between 24 December 2012 and 17 January 2013 was relatively warm, with calibrated AWS temperatures of $\sim 1-5^{\circ} \mathrm{C}$ for most days (Fig. 9e). We note that these are $2 \mathrm{~m}$ air temperatures and that once surface melting commenced, actual surface temperatures would be lower but still above freezing. The daily RACMO SMB data also show two accumulation events during the last week of December 2012 (Fig. 9d), which involved rain on snow (M. Truffer, personal communication, 2016). Surface elevations decreased by $\sim 0.2-0.3 \mathrm{~m}$ across the entire GPS array during this warm and rainy period (Fig. 9b), which is consistent with surface melting and/or enhanced firn-compaction rates. No corresponding short-term changes were recorded by the antenna elevations during the $\sim 3-4$-week period (Fig. 9a), suggesting that the processes responsible for the observed surface changes did not affect the firn layers near the pole base $(\sim 1.5 \mathrm{~m}$ depth). We note that there are many warm periods between 1979 and 2015 with greater magnitude and duration than the December 2012 to January 2013 period in the ERA-Interim $2 \mathrm{~m}$ air temperatures over the PIG shelf.

\subsection{Firn model}

Figure $7 \mathrm{c}$ shows that the IMAU-FDM simulated surface elevation $\left(\widetilde{z_{\text {surf }}}\right)$ ranges from -0.1 to $+0.4 \mathrm{~m}$ from 2008 to 2010 and -0.2 to $+0.2 \mathrm{~m}$ from 2012 to 2014 . The observed $\mathrm{D} \widetilde{z_{\text {surf }}} / \mathrm{D} t$ trend is $+0.17 \mathrm{~m} \mathrm{yr}^{-1}$ from 2008 to 2010 , with no significant trend from 2012 to 2014. The magnitude and timing of the simulated surface elevation variability is consistent with the detrended observed surface elevation change (Fig. 9b). The observed $\mathrm{D} z_{\text {surf }} / \mathrm{D} t$ trends $\left(-1\right.$ to $\left.-4 \mathrm{~m} \mathrm{yr}^{-1}\right)$, however, cannot be explained by simulated elevation change due to SMB and firn processes (Fig. 7c).

\subsection{Basal melt rates}

We computed basal melt rates from surface $\mathrm{D} z_{\text {surf }} / \mathrm{D} t$ elevation change using Eq. (5). The resulting melt rate estimates range from $\sim 2 \mathrm{~m} \mathrm{yr}^{-1}$ at PIG2 to $\sim 39 \mathrm{~m} \mathrm{yr}^{-1}$ at SOW3 (Table 1).

The 2012-2014 melt rate estimates show significant spatial variability. The three upstream stations (SOW1, SOW2, and BOAR) experienced lower melt rates of $\sim 9-13 \mathrm{~m} \mathrm{yr}^{-1}$, while the downstream stations near the transverse depression (SOW3 and SOW4) experienced higher rates of $\sim 29$ $39 \mathrm{~m} \mathrm{yr}^{-1}$ for the same time period.

\subsection{High-resolution DEMs}

Figure 8 shows sampled DEM elevation compared with GPS surface elevation at each site, with statistics provided in Table 2 . In general, we observe good agreement between the two datasets, with RMSE of $0.72 \mathrm{~m}$ and NMAD of $0.57 \mathrm{~m}$ for the full sample $(n=25)$. The DEMs display a slight bias $(+0.43 \mathrm{~m})$ relative to the GPS surface elevation.

We observe good agreement between GPS-derived (Table 1) and DEM-derived (Table 2) $\mathrm{D} z_{\text {surf }} / \mathrm{D} t$ trends. The shorter $\mathrm{DEM} \mathrm{D} z_{\text {surf }} / \mathrm{D} t$ intervals (e.g., $\sim 1$ year for SOW 1 and BOAR) display larger errors than longer DEM intervals ( $\sim 2$ years for SOW2 and SOW 3 ).

Figure 10 shows the composite DEM-derived $\mathrm{D} z_{\text {surf }} / \mathrm{D} t$ maps, which provide spatial context for the GPS-derived $\mathrm{D} z_{\text {surf }} / \mathrm{D} t$ records. Little or no elevation change was observed over longitudinal ridges, while areas within and near transverse depressions experienced enhanced thinning. This thinning was concentrated on the upstream side of the transverse depressions. The $\mathrm{D} z_{\text {surf }} / \mathrm{D} t$ products relative to the 23 October 2012 DEM (Fig. 10d) also show the spatial pattern of thinning associated with the rift that opened upstream of SOW1 in 2014 (Jeong et al., 2016). 

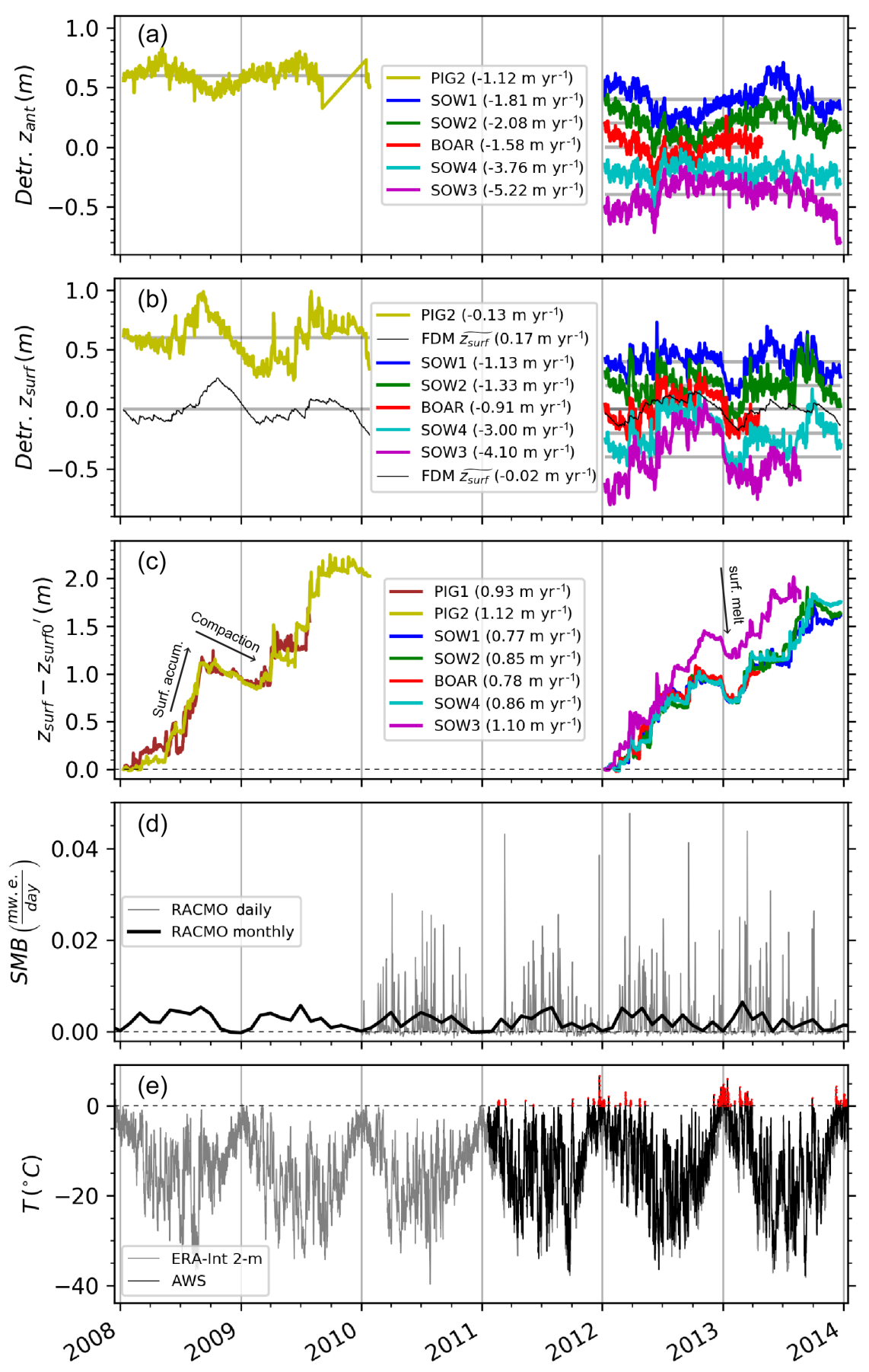

Figure 9. (a) Detrended GPS antenna elevation ( $z_{\text {ant }}$, see Fig. $7 \mathrm{~b}$ for original records), with arbitrary $y$-axis offset. The legend lists linear trends, which can be compared with $\mathrm{D} z_{\text {surf }} / \mathrm{D} t$ trend in panel (b) (see Eq. 6). (b) Detrended surface elevation $\left(z_{\text {surf }}\right.$, see Fig. $\left.7 \mathrm{c}\right)$ and detrended IMAU-FDM simulated surface elevation $\left(\widetilde{z_{\text {surf }}}\right)$, with arbitrary $y$-axis offset. The legend lists linear trends. Note limited residual magnitude and dampened seasonal signal of $z_{\text {ant }}$ compared to $z_{\text {surf }}$. Unlike $z_{\text {surf }}$, no significant change is observed in $z_{\text {ant }}$ from December 2012 to January 2013. (c) Surface elevation relative to tracer for initial surface $\left(z_{\text {surf }}-z_{\text {surfo }}\right)$. As annotated, positive slopes are indicative of new snow accumulation, shallow negative slopes indicate ongoing compaction, and steep negative slopes likely indicate surface melt. Note $\sim 0.2-$ $0.3 \mathrm{~m}$ surface decrease from December 2012 to January 2013. Legend values show linear fit at each site. (d) Daily and monthly RACMO2.3 SMB. Note correlation of accumulation events and increases in panel (c). (e) Scaled 2 m temperature data from Evans Knoll AWS (black) and ERA-Interim (gray), with above-zero AWS temperatures plotted in red. Note extended warm period from mid-December 2012 to midJanuary 2013, which corresponds to $\sim 0.2-0.3 \mathrm{~m}$ surface elevation decrease in panels (b) and (c). 
Table 2. Statistics for WorldView DEM accuracy from comparisons with measured GPS surface elevation data. Asterisks identify records with shorter time interval and increased uncertainty.

\begin{tabular}{lcccccc}
\hline Site & $\begin{array}{c}\text { DEM } \\
n\end{array}$ & $\begin{array}{c}\text { DEM d } t \\
(\text { days })\end{array}$ & $\begin{array}{c}\text { DEM D } z_{\text {surf }} / \mathrm{D} t \\
\left(\mathrm{~m} \mathrm{yr}^{-1}\right)\end{array}$ & $\begin{array}{c}\text { GPS-DEM RMSE } \\
(\mathrm{m})\end{array}$ & $\begin{array}{c}\text { GPS-DEM mean } \\
(\mathrm{m})\end{array}$ & $\begin{array}{c}\text { GPS-DEM SD } \\
(\mathrm{m})\end{array}$ \\
\hline SOW1 & 5 & $302^{*}$ & -2.30 & 0.69 & -0.26 & 0.64 \\
SOW2 & 5 & 619 & -2.03 & 0.76 & -0.46 & 0.60 \\
BOAR & 4 & $302^{*}$ & -1.69 & 0.86 & -0.55 & 0.66 \\
SOW4 & 5 & $368^{*}$ & -3.35 & 0.75 & -0.61 & 0.44 \\
SOW3 & 6 & 619 & -4.32 & 0.54 & -0.30 & 0.45 \\
\hline
\end{tabular}

\section{Assumptions}

The methods presented in Sect. 2 relied on several simplifying assumptions. We now offer further discussion of these assumptions and their potential influence on our results.

\subsection{Hydrostatic equilibrium}

In the absence of direct ice thickness measurements (e.g., radar profiles near PIG GPS sites), we assume hydrostatic equilibrium and use surface elevation to estimate freeboard ice thickness - a standard practice for ice-shelf studies. While this assumption can lead to increased uncertainty within a few ice thicknesses of the grounding line (Brunt et al., 2010; Griggs and Bamber, 2011), it is reasonable for the mid-shelf location of the GPS array, which in $\sim 2012$, had been approaching hydrostatic equilibrium for over 10-12 years since crossing the grounding line.

Previous studies using airborne ice-penetrating radar data have noted that most of the PIG shelf is generally near hydrostatic equilibrium (Bindschadler et al., 2011; Dutrieux et al., 2013; Vaughan et al., 2012). Dense radar grids, however, reveal narrow shelf-bottom channels, crevasses, and other features with horizontal length scales of $\sim 10$ s -100 s of meters that are not apparent in ice-shelf surface topography (Langley et al., 2014; Vaughan et al., 2012). The thinner ice above these narrow features is partially supported by lateral bridging stresses, so that the corresponding surface elevation will appear higher than the expected freeboard surface elevation, providing erroneously large ice thickness estimates using Eq. (4) (Drews, 2015; Shabtaie and Bentley, 1982; Vaughan et al., 2012).

Experiments with a high-resolution ice-flow model show that wider basal channels tend to be near equilibrium, while increased bridging stresses support ice over narrow basal channels (Drews, 2015). The PIG GPS array is $\sim 2 \mathrm{~km}$ across, which is $>4-5 \times$ the local ice thickness $(\sim 350$ $500 \mathrm{~m})$. The $\sim 1-2 \mathrm{~km}$ length scale of nearby longitudinal channels/keels is $>2-3 \times$ the local ice thickness, with typical surface elevation difference between trough floors and adjacent ridge crests of $<10 \mathrm{~m}$. For the observed ice thickness, magnitude, and length scale of surface variations, as well as the relatively long timescales involved, we argue that the hydrostatic assumption is reasonable, and any vertical elevation change due to evolving bridging stresses should be negligible compared to the magnitude of observed $\mathrm{D} z_{\text {surf }} / \mathrm{D} t$ and our conservative error estimates.

\subsection{SMB spatial variability}

We used modeled SMB from a single RACMO2.3 grid cell to drive the IMAU-FDM dynamic firn model, and applied the result to all GPS stations. We expect SMB to vary spatially (e.g., Medley et al., 2015) due to local environmental conditions (e.g., PIG2 elevation is $>400 \mathrm{~m}$ higher than SOW1-4 stations on the shelf) and local surface topography (e.g., kilometer-scale ridges/troughs), which will affect nearsurface winds and snow redistribution.

The larger $z_{\text {surf }}-z_{\text {surfo }}{ }^{\prime}$ values (a proxy for surface accumulation) at SOW3 (Fig. 9c) indicate that greater local accumulation occurred at this site within the transverse depression (Fig. 2), potentially due to preferential deposition of wind-blown snow. However, we also note that the accumulation histories of SOW4, which sits near a surface ridge crest, and the three sites located on the floor of a broad, flat surface trough (SOW1, SOW2, BOAR) appear similar (Fig. 9c).

The IMAU-FDM values do not account for horizontal advection of the firn column through spatially variable RACMO fields (accumulation, surface temperature, etc.) over time. The GPS sites over the PIG shelf are moving $\sim 4 \mathrm{~km} \mathrm{yr}^{-1}$ (Figs. 1 and 5), which is nearly double the observed PIG shelf velocities from the mid-1970s (Mouginot et al., 2014). Thus, the local firn columns beneath the GPS sites likely experienced variable SMB input over their $\sim 50$ $100 \mathrm{~km}$ horizontal path during the corresponding 1979-2015 time period. This suggests that the true firn column thickness and compaction rates may differ from the IMAU-FDM estimates. For this reason, we use a constant firn air content estimate $(d \approx 12 \pm 2 \mathrm{~m})$ derived from available airborne icepenetrating radar two-way travel time and altimetry surface elevation measurements (see Appendix A of Shean, 2016).

\subsection{Pole settling/tilting}

We now consider whether some of the observed $\mathrm{D} z_{\text {surf }} / \mathrm{D} t$ could be related to settling, heating, or tilting of the GPS 

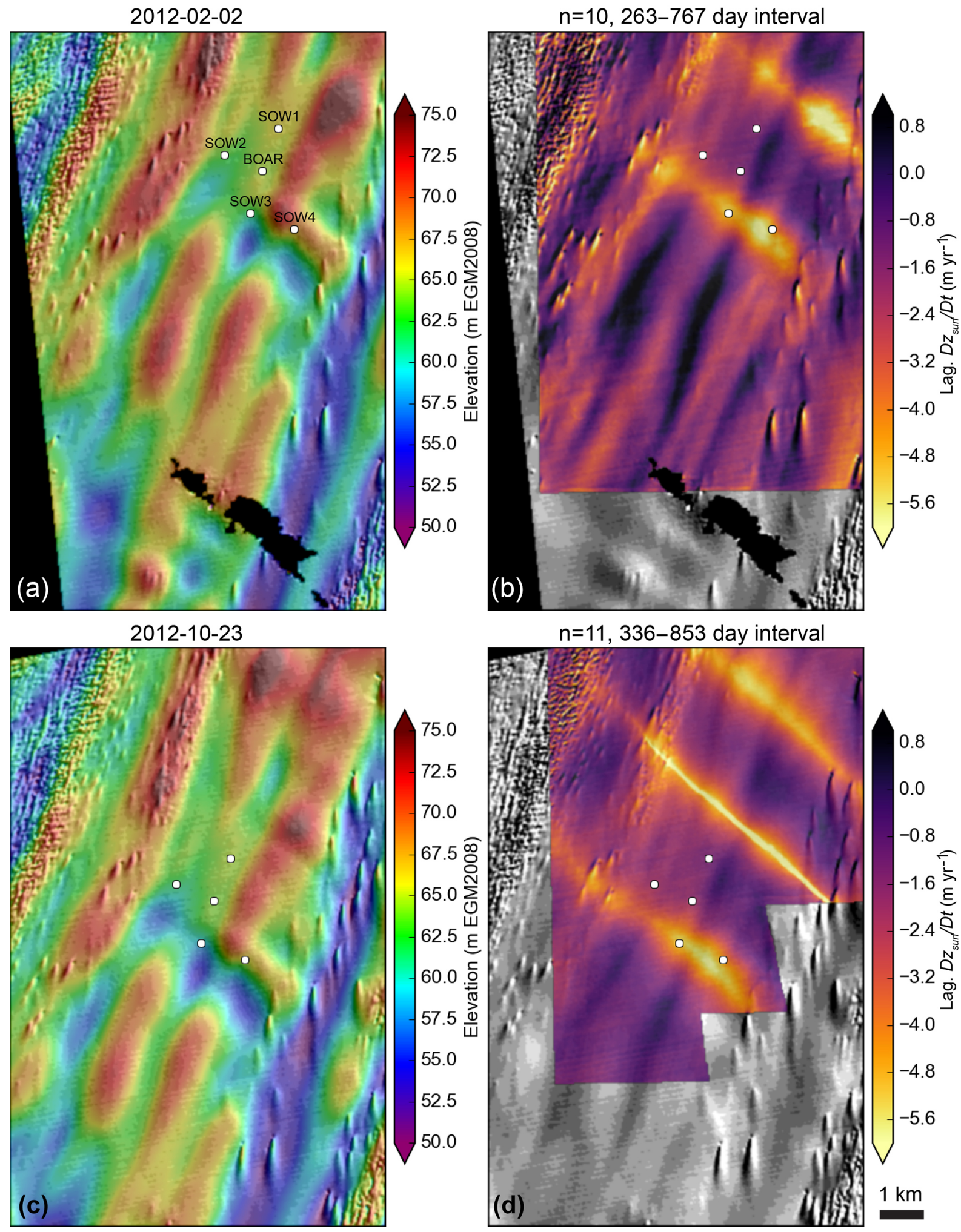

Figure 10. WorldView DEMs and composite Lagrangian $\mathrm{D} z_{\text {surf }} / \mathrm{D} t$ products generated using (a-b) initial DEM from 2 February 2012 and (c-d) initial DEM from 23 October 2012. Note enhanced thinning observed within transverse depressions and rift upstream of GPS array. The $\mathrm{D} z_{\text {surf }} / \mathrm{D} t$ maps are used to calculate basal melt rates (scaling factor of $\sim 9$, e.g., $\mathrm{D} z_{\text {surf }} / \mathrm{D} t$ of $\sim 1 \mathrm{~m} \mathrm{yr}^{-1}$ corresponds to a basal melt rate estimate of $\sim 9-10 \mathrm{~m} \mathrm{yr}^{-1}$ ). 
poles over time. We assume that the poles froze in place shortly after installation, and the contact area $\left(\sim 1200 \mathrm{~cm}^{2}\right.$ for a $\sim 1 \mathrm{~m}$ long cylinder with $\sim 3.8 \mathrm{~cm}$ diameter) with surrounding firn should be sufficient to counter the downward gravitational force. Thus, we expect that antenna elevation change $\left(\mathrm{D} z_{\text {ant }} / \mathrm{D} t\right)$ represents rates at the base of the pole rather than rates within an overlying firn layer.

A related consideration involves heating of the exposed pole during summer, which might lead to decoupling from the surrounding snow/firn and allow for additional penetration of the pole base within the firn. The pole-base stoppers should have prevented this penetration. In addition, we do not see any indication of such settling from December 2012 to January 2013, when surface elevations decreased by $\sim 0.2$ $0.3 \mathrm{~m}$, but pole-base elevations showed little change (Fig. 9a and $b$ ). The lack of pole-base elevation change also suggests that surface meltwater did not percolate more than $\sim 1-2 \mathrm{~m}$ below the surface.

Finally, we assume that the poles were installed with vertical orientation and did not tilt over time. For an initially vertical pole with length of $3.71 \mathrm{~m}$ (including antenna phasecenter offset), a $10^{\circ}$ tilt would introduce a $-0.06 \mathrm{~m}$ vertical antenna elevation error $\left(-0.03 \mathrm{~m} \mathrm{yr}^{-1}\right.$ for a 2 -year period), while a $20^{\circ}$ tilt would introduce a $-0.22 \mathrm{~m}$ vertical error $\left(-0.11 \mathrm{~m} \mathrm{yr}^{-1}\right)$. Thus, we expect vertical error associated with any tilting to be negligible compared to the large observed $\mathrm{D} z_{\text {ant }} / \mathrm{D} t\left(-1.12\right.$ to $\left.-7.60 \mathrm{~m} \mathrm{yr}^{-1}\right)$. These 10 and $20^{\circ}$ tilts could, however, introduce horizontal errors of up to 0.64 and $1.27 \mathrm{~m}$, respectively, which would affect intranetwork displacement and strain rate estimates. While it is possible that some minor tilting could have occurred (especially during initial months), this was not noted during servicing/removal, and the reflectometry results do not indicate any systematic change in directional antenna-surface offset.

\subsection{Strain rate length scales}

We estimated $\sim 0.1 \mathrm{~m} \mathrm{yr}^{-1}$ surface elevation change due to local flux divergence, assuming that the observed relative horizontal displacements are evenly distributed across the strain triangles, which have $\sim 1-2 \mathrm{~km}$ edges between GPS stations. This assumption is supported by the $\sim 1 \mathrm{~km}$ spatial extent of thinning signals within/near transverse depressions in the $\mathrm{D} z_{\text {surf }} / \mathrm{D} t$ maps (Fig. 10). Even if this strain is concentrated over a shorter distance (e.g., $\sim 200 \mathrm{~m}$ ), this contribution only increases to $\sim 0.5 \mathrm{~m} \mathrm{yr}^{-1}$, which is still small compared to observed $\mathrm{D} z_{\text {surf }} / \mathrm{D} t$ signals of $\sim 3-4 \mathrm{~m} \mathrm{yr}^{-1}$. The relatively large spatial variability in $\mathrm{D} z_{\text {surf }} / \mathrm{D} t$ values $(\sim 1$ to $\sim 4 \mathrm{~m} \mathrm{yr}^{-1}$ ) and lack of spatial variability in strain rates supports the assumption that the observed $\mathrm{D} z_{\text {surf }} / \mathrm{D} t$ is primarily caused by basal melt.

\section{Discussion}

\subsection{SMB and firn compaction}

The evolution of GPS-derived surface elevation relative to a tracer for the initial surface $\left(z_{\text {surf }}-z_{\text {surf0 }}^{\prime}\right)$ is consistent with SMB estimates $(\dot{a})$, providing qualitative validation for the RACMO SMB and IMAU-FDM results. Based on these results, we suggest that it may be possible to extract detailed SMB records for other sites using only observed GPS antenna-surface distance and simple assumptions about firn densification (e.g., Herron and Langway Jr., 1980). The problem is further simplified for grounded ice with negligible $\mathrm{BMB}$ rates.

The limited variability in surface elevation at PIG2 (Fig. 7c) suggests that the observed 2008-2010 SMB over the south PIG shelf was approximately equal to basal melt during this period, assuming negligible velocity divergence for this location. We observe large surface elevation trends for the 2012-2014 GPS sites with no significant simulated $\mathrm{D} \widetilde{z_{\text {surf }}} / \mathrm{D} t$ trend, suggesting that SMB and firn compaction during this period were consistent with average 1979-2015 SMB $(\bar{a})$ values, and that the large observed $\mathrm{D} z_{\text {surf }} / \mathrm{D} t$ must be attributed to other processes, specifically basal melting.

\subsection{Residual elevation variability}

The detrended surface (Fig. 9a) and antenna (Fig. 9b) elevation residuals appear unrelated. This suggests that seasonal surface processes (e.g., accumulation influencing nearsurface compaction rates) are not responsible for driving antenna elevation variability. We considered several possible sources for the observed subannual elevation variability, including ocean (e.g., currents, sea surface height), atmospheric (e.g., pressure, temperature), and dynamic processes (e.g., resistive stress from sea ice and/or mélange in shear margins). Unfortunately, we were unable to definitively determine the cause(s) for these variations in the $\sim 2$-year GPS records.

Some of the short-term (days-weeks) variability (e.g., June 2012) observed across all five 2012-2014 stations (Fig. 9b) could be related to insufficient or incorrect IBE correction. The magnitude and timing of these systematic anomalies, however, suggests that they are likely related to grounding/ungrounding events (e.g., Joughin et al., 2016).

\subsection{Strain rate history, rifting, and grounding evolution}

The lateral shear across the GPS array is consistent with increased longitudinal extension closer to the PIG centerline, potentially due to locally enhanced ductile deformation (i.e., "necking"; Bassis and Ma, 2015) across transverse depressions and/or expansion of basal/surface crevasses and rifts. The SOW3 station, which lies within a large transverse depression (Fig. 2), displays a slight acceleration in antenna 
elevation change (Fig. 9a), potentially due to increased local extension within the depression.

An upstream regrounding event would slow ice upstream of the GPS array, initially resulting in increased extensional strain rates across the transverse rifts/depressions, followed by a velocity decrease at the GPS array. Conversely, an upstream ungrounding event would initially lead to decreased extensional strain rates across the transverse rifts/depressions, followed by an increase in observed GPS velocities. We suggest that an upstream regrounding event (Joughin et al., 2016) in $\sim$ June 2012 could be responsible for increased strain rates across the GPS array (Fig. 6). Similarly, an ungrounding event in $\sim$ April 2013 followed by a grounding event in $\sim$ November 2013 could explain the decrease and subsequent increase in strain rates.

There is an abrupt $\sim 0.1-0.2 \mathrm{~m}$ antenna elevation $\left(z_{\text {ant }}\right)$ decrease at both SOW3 and SOW4 in late 2013, near the end of the records (Fig. 9a). No surface elevation $\left(z_{\text {surf }}\right)$ information is available at SOW3 due to missing antenna-surface distance data for this period (see Sect. 2.3), but a corresponding surface elevation decrease is observed at SOW4 (Fig. 9b). These elevation decreases do not appear to be related to site servicing. Rather, these observations are consistent with relatively abrupt local extension within the transverse depression affecting SOW3 and SOW4 but not the upstream GPS sites. The timing of this event corresponds with observed lengthening of the large rift (R1) upstream of SOW1 (Jeong et al., 2016), supporting the hypothesis that relatively rapid, localized extension occurred across the transverse depressions and rifts during this period.

\subsection{Comparison with in situ basal melt rate observations}

The GPS-derived basal melt rate estimates $\left(\sim 9-13 \mathrm{~m} \mathrm{yr}^{-1}\right.$ for SOW1, SOW2, and BOAR sites) appear consistent with those from bottom altimeter $\left(\sim 14.7 \mathrm{~m} \mathrm{yr}^{-1}\right.$ from January to February 2012) and pRES $\left(\sim 15-25 \mathrm{~m} \mathrm{yr}^{-1}\right)$ measurements of Stanton et al. (2013). These measurements provide some validation for the GPS results, as they are not influenced by surface mass balance and firn processes. A direct comparison may be imprudent, however, as the Stanton et al. (2013) borehole was $\sim 1.34 \mathrm{~km}$ upstream of SOW1 (near the R1 rift), which likely affected local melt rates, and we observe considerable $\sim$ kilometer-scale spatial variability in melt rates across GPS array. Furthermore, the bottom altimeter sampled a $\sim 5 \mathrm{~cm}$ diameter spot with unknown upstream/downstream orientation, approximately $30-40 \mathrm{~cm}$ from the edge of the $20 \mathrm{~cm}$ borehole. Aside from local melt variability expected due to turbulent flow near the altimeter pole or borehole edge, the altimeter provided a relatively small spatial sample compared to the GPS results, which are sensitive to changes in a column of ice with much larger footprint (100s to 1000s of $\left.\mathrm{m}^{2}\right)$.

\subsection{Basal melt rate spatial variability}

The GPS records at SOW1, SOW2, and BOAR show similar $\mathrm{D} z_{\text {surf }} / \mathrm{D} t$ rates and residuals, which is consistent with their apparent orientation on the same "block" between transverse rifts/depressions (Fig. 2) and supports the hypothesis that they were exposed to similar sub-shelf circulation. The $\mathrm{DEM} \mathrm{D} z_{\text {surf }} / \mathrm{D} t$ maps show enhanced surface elevation change rates, and thus higher basal melt rates, on the upstream side of transverse depressions (Fig. 10), which is consistent with increased $\mathrm{D} z_{\text {surf }} / \mathrm{D} t$ observed at the SOW3 and SOW4 sites.

This relationship is potentially related to enhanced buoyant flow and/or turbulence over increased basal slopes (e.g., Jenkins, 2011) beneath transverse surface depressions. We also suggest that these transverse basal channels may offer conduits for meltwater flow between adjacent longitudinal channels, potentially leading to increased circulation velocity and higher melt rates within the transverse depressions.

\subsection{Basal melt rate sensitivity to ocean temperature variability}

Christianson et al. (2016) suggest that the subtle $(\sim 2-4 \%)$ changes in 2012-2014 GPS velocity display a lagged correlation with observed variations in ocean temperature records from moorings in Pine Island Bay (see Fig. 1 for location), potentially implying causality. Our analysis supports the alternative hypothesis of Christianson et al. (2016) that these velocity variations are primarily related to upstream grounding evolution (Joughin et al., 2016) and extension across a series of transverse depressions.

Rates of antenna and surface elevation change $\left(\mathrm{D} z_{\text {ant }} / \mathrm{D} t\right.$ and $\left.\mathrm{D} z_{\text {surf }} / \mathrm{D} t\right)$ were essentially constant in time, with no significant variation in inferred basal melt rates during this 2-year time period. If sub-shelf melt rates beneath the GPS array covaried with observed ocean heat content beyond the shelf front in Pine Island Bay (Christianson et al., 2016; Webber et al., 2017), a significant change in both $\mathrm{D} z_{\text {ant }} / \mathrm{D} t$ and $\mathrm{D} z_{\text {surf }} / \mathrm{D} t$ would be expected during this period. The lack of any significant deviation suggests that melt rates at these sites were not noticeably affected by observed ocean temperature variability. This finding suggests that (1) these sites are not representative of melt rates for the inner shelf (e.g., those near the grounding line), (2) the oceanographic measurements near the PIG ice front are not representative of water circulating beneath these ice-shelf sites, and/or (3) local melt rates are less sensitive to the observed oceanographic changes than previously assumed.

\subsection{Future work}

High-resolution velocity maps derived from submeter imagery could potentially constrain local velocity divergence and length scales for observed strain between GPS receivers. 
In addition, seismic data from stations deployed near the GPS array and regional sites could help constrain the timing and location of rift propagation and grounding/ungrounding events.

High-resolution ( $<1 \mathrm{~km}$ grid) SMB output and improved dynamic firn model output would likely offer an improved understanding of local variability across the GPS array. It may also be possible to further constrain firn-compaction rates, and thus long-term SMB, using relative layer thicknesses observed in CReSIS snow radar measurements (e.g., Medley et al., 2015) or in situ pRES observations (e.g., Jenkins et al., 2006). However, airborne radar data over the PIG shelf suffer from clutter due to kilometer-scale surface/basal topography and crevasses, while the available intermittent pRES records (Stanton et al., 2013) likely lack the sensitivity to detect small changes in firn layer thickness during the $\sim$ 3-week observation period.

These limitations highlight the current value of long-term GPS records to constrain surface evolution where observations are sparse and model results are poorly constrained. Expanding the scope of our study to include the full archive of geodetic GPS data for the Antarctic and Greenland ice sheets would offer a valuable new dataset for calibration/validation of models and remote sensing data.

We offer the following recommendations to improve GPSIR results for future GPS deployments: (1) set the GPS elevation mask to $0^{\circ}$ (default values are typically $\sim 5$ $\left.10^{\circ}\right)$, (2) track all possible signals (L2C, L5, Galileo, and GLONASS), (3) ensure that antenna-surface distance will remain $>0.5 \mathrm{~m}$ between servicing visits, and (4) document and photograph GPS sites, noting antenna-surface distance and any pole tilt during install and servicing.

\section{Summary and conclusions}

We analyzed GPS records for the PIG shelf for the 20082010 and 2012-2014 periods. We produced daily time series of antenna-surface distance ( $\left.h_{\text {ant-surf }}\right)$ and antenna elevation ( $z_{\text {ant }}$, relative to EGM2008 geoid), which were combined to accurately measure surface elevation $\left(z_{\text {surf }}\right)$ at each site. The surface elevation data can be directly compared with remotesensing measurements, providing independent validation for high-resolution WorldView stereo DEM records (RMSE of $\sim 0.72 \mathrm{~m}, \mathrm{NMAD}$ of $\sim 0.57 \mathrm{~m}$ ).

The GPS-derived surface elevation data provide new information about local SMB that can be compared with coarse-resolution model output and AWS data. Surface elevation relative to a firn layer tracer for the initial surface $\left(z_{\text {surf }}-z_{\text {surfo }}{ }^{\prime}\right)$ increased at rates of $\sim 0.8-1.1 \mathrm{~m} \mathrm{yr}^{-1}$ for all GPS sites, which is consistent with modeled SMB of $\sim 0.7$ $0.9 \mathrm{~m}$ w.e. $\mathrm{yr}^{-1}$. An abrupt $\sim 0.2-0.3 \mathrm{~m}$ surface elevation decrease, likely due to surface melt and/or enhanced firn compaction, is observed across all GPS sites during a period of warmer atmospheric temperatures from December 2012 to January 2013.

Trends in observed antenna $\left(\mathrm{D} z_{\text {ant }} / \mathrm{D} t\right)$ and surface elevation change $\left(\mathrm{D} z_{\text {surf }} / \mathrm{D} t\right)$ were highly linear for all GPS sites on the PIG shelf. Observed extensional strain rates were $\sim 0.001-0.002 \mathrm{yr}^{-1}$ for the 2012-2014 GPS array, which corresponds to only $\sim 0.1 \mathrm{~m} \mathrm{yr}^{-1}$ surface elevation change due to local flux divergence.

An alternative form of the mass conservation equation was used to estimate BMB from observed Lagrangian surface elevation change, strain rates, and SMB. Basal melt rates were $\sim 10$ to $\sim 40 \mathrm{~m} \mathrm{yr}^{-1}$ near the center of the fast-flowing PIG shelf, and $\sim 2 \mathrm{~m} \mathrm{yr}^{-1}$ for the southern shelf. These melt rates are similar to those derived from complementary in situ instrument records (Stanton et al., 2013) and high-resolution stereo DEMs (Shean, 2016).

Both GPS and DEM records show higher basal melt rates within and near transverse surface depressions and rifts associated with longitudinal extension. Basal melt rates for the 2012-2014 period show limited temporal variability, despite substantial changes in ocean heat content at the ice front and likely in the ice-shelf cavity. Residual elevation change variability is likely related to upstream grounding/ungrounding events and the local evolution of transverse depressions/rifts. Our results demonstrate the value of long-term GPS records and interferometric reflectometry for constraining ice-shelf mass balance estimates.

Data availability. All GPS data are available from the UNAVCO archive (https://www.unavco.org/data/data.html). ERAInterim products are available from https://www.ecmwf.int/en/ forecasts/datasets/reanalysis-datasets/era-interim. AWS data are available from AMRC/AMS (https://amrc.ssec.wisc.edu/). The DigitalGlobe images used to generate DEMs were provided by the Polar Geospatial Center at the University of Minnesota, under the NGA NextView License. Derived DEM products are available upon request.

Competing interests. The authors declare that they have no conflict of interest.

Acknowledgements. David Shean was supported by a NASA NESSF fellowship (NNX12AN36H). Knut Christianson was supported by NASA grants NNX16AM01G and NNX12AB69G and NSF grant 0732869. Kristine Larson was supported by NSF AGS-1449554. Stefan Ligtenberg was supported by an NWO ALW Veni grant (865.15.023). An NSF OPP grant to CReSIS (ANT-0424589) and a NASA grant (NNX15AD54G) provided support for Ian Joughin and additional support for David Shean. David Holland and Mitch Bushuk acknowledge support from NSF grant PLR-0732869 and NYU Abu Dhabi grant G1204. Howard Conway provided useful feedback on an earlier version of this paper and discussions with Pierre Dutrieux helped guide interpretation. Melchior van Wessem, Peter Kuipers Munneke, and 
Michiel van den Broeke provided RACMO SMB products. The AWS data are available from the University of Wisconsin-Madison Automatic Weather Station Program (NSF ANT-1245663). We acknowledge the substantial effort required to obtain the GPS data used in this study, involving multiple PIG field campaigns led by Robert Bindschadler and Martin Truffer, with significant contributions from many others. We acknowledge GPS data collection and archiving provided by the UNAVCO Facility with support from NSF and NASA under NSF Cooperative Agreement no. EAR-0735156. Resources supporting the DEM generation were provided by the NASA High-End Computing (HEC) Program through the NASA Advanced Supercomputing (NAS) Division at Ames Research Center. We thank Laurence Padman and an anonymous reviewer for their comments and suggestions, which significantly improved this paper.

Edited by: G. Hilmar Gudmundsson

Reviewed by: Laurence Padman and one anonymous referee

\section{References}

Andreassen, L. M., Elvehøy, H., Kjøllmoen, B., and Engeset, R. V.: Reanalysis of long-term series of glaciological and geodetic mass balance for 10 Norwegian glaciers, The Cryosphere, 10, 535-552, https://doi.org/10.5194/tc-10-535-2016, 2016.

Arthern, R. J., Vaughan, D. G., Rankin, A. M., Mulvaney, R., and Thomas, E. R.: In situ measurements of Antarctic snow compaction compared with predictions of models, J. Geophys. Res., 115, F03011, https://doi.org/10.1029/2009JF001306, 2010.

Bassis, J. N. and Ma, Y.: Evolution of basal crevasses links ice shelf stability to ocean forcing, Earth Planet. Sci. Lett., 409, 203-211, https://doi.org/10.1016/j.eps1.2014.11.003, 2015.

Bindschadler, R., Vaughan, D. G., and Vornberger, P.: Variability of basal melt beneath the Pine Island Glacier ice shelf, West Antarctica, J. Glaciol., 57, 581-595, 2011.

Bindschadler, R. A.: History of lower Pine Island Glacier, West Antarctica, from Landsat imagery, J. Glaciol., 48, 536-544, 2002.

Brunt, K. M., Fricker, H. A., Padman, L., Scambos, T. A., and O'Neel, S.: Mapping the grounding zone of the Ross Ice Shelf, Antarctica, using ICESat laser altimetry, Ann. Glaciol., 51, 7179, 2010.

Christianson, K., Bushuk, M., Dutrieux, P., Parizek, B. R., Joughin, I. R., Alley, R. B., Shean, D. E., Abrahamsen, E. P., Anandakrishnan, S., Heywood, K. J., Kim, T.-W., Lee, S. H., Nicholls, K., Stanton, T., Truffer, M., Webber, B. G. M., Jenkins, A., Jacobs, S., Bindschadler, R., and Holland, D. M.: Sensitivity of Pine Island Glacier to observed ocean forcing: PIG response to ocean forcing, Geophys. Res. Lett., 43, 10817-10825, https://doi.org/10.1002/2016GL070500, 2016.

Church, J. A., Cazenave, A., Gregory, J. M., Jevrejeva, S., Levermann, A., Merrifield, M. A., Milne, G. A., Nerem, R. S., Nunn, P. D., Payne, A. J., Pfeffer, W. T., Stammer, D., and Unnikrishnan, A. S.: Sea Level Change, available at: http://www.ipcc.ch/pdf/assessment-report/ar5/wg1/ WG1AR5_Chapter13_FINAL.pdf (last access: 7 January 2015), 2013.
Dee, D. P., Uppala, S. M., Simmons, A. J., Berrisford, P., Poli, P., Kobayashi, S., Andrae, U., Balmaseda, M. A., Balsamo, G., Bauer, P., Bechtold, P., Beljaars, A. C. M., van de Berg, L., Bidlot, J., Bormann, N., Delsol, C., Dragani, R., Fuentes, M., Geer, A. J., Haimberger, L., Healy, S. B., Hersbach, H., Hólm, E. V., Isaksen, L., Kållberg, P., Köhler, M., Matricardi, M., McNally, A. P., Monge-Sanz, B. M., Morcrette, J.-J., Park, B.-K., Peubey, C., de Rosnay, P., Tavolato, C., Thépaut, J.-N., and Vitart, F.: The ERA-Interim reanalysis: configuration and performance of the data assimilation system, Q. J. Roy. Meteor. Soc., 137, 553-597, https://doi.org/10.1002/qj.828, 2011.

Depoorter, M. A., Bamber, J. L., Griggs, J. A., Lenaerts, J. T. M., Ligtenberg, S. R. M., van den Broeke, M. R., and Moholdt, G.: Calving fluxes and basal melt rates of Antarctic ice shelves, Nature, 502, 89-92, https://doi.org/10.1038/nature12567, 2013.

Drews, R.: Evolution of ice-shelf channels in Antarctic ice shelves, The Cryosphere, 9, 1169-1181, https://doi.org/10.5194/tc-91169-2015, 2015.

Dutrieux, P., Vaughan, D. G., Corr, H. F. J., Jenkins, A., Holland, P. R., Joughin, I., and Fleming, A. H.: Pine Island glacier ice shelf melt distributed at kilometre scales, The Cryosphere, 7, 15431555, https://doi.org/10.5194/tc-7-1543-2013, 2013.

Dutrieux, P., De Rydt, J., Jenkins, A., Holland, P. R., Ha, H. K., Lee, S. H., Steig, E. J., Ding, Q., Abrahamsen, E. P., and Schroder, M.: Strong Sensitivity of Pine Island IceShelf Melting to Climatic Variability, Science, 343, 174-178, https://doi.org/10.1126/science.1244341, 2014.

Ettema, J., van den Broeke, M. R., van Meijgaard, E., van de Berg, W. J., Bamber, J. L., Box, J. E., and Bales, R. C.: Higher surface mass balance of the Greenland ice sheet revealed by highresolution climate modeling, Geophys. Res. Lett., 36, L12501, https://doi.org/10.1029/2009GL038110, 2009.

Frezzotti, M., Scarchilli, C., Becagli, S., Proposito, M., and Urbini, S.: A synthesis of the Antarctic surface mass balance during the last $800 \mathrm{yr}$, The Cryosphere, 7, 303-319, https://doi.org/10.5194/tc-7-303-2013, 2013.

Gao, J. and Liu, Y.: Applications of remote sensing, GIS and GPS in glaciology: a review, Prog. Phys. Geogr., 25, 520-540, 2001.

Griggs, J. A. and Bamber, J. L.: Antarctic ice-shelf thickness from satellite radar altimetry, J. Glaciol., 57, 485-498, 2011.

Hamilton, G. S. and Whillans, I. M.: First point measurements of ice-sheet thickness change in Antarctica, Ann. Glaciol., 27, 125129, 1998.

Hawley, R. L. and Waddington, E. D.: Instruments and Methods In situ measurements of firn compaction profiles using borehole optical stratigraphy, J. Glaciol., 57, 289-294, 2011.

Herring, T. A., King, R. W., and McClusky, S. C.: Introduction to GAMIT/GLOBK, available at: http://chandler.mit.edu/ simon/ gtgk/Intro_GG.pdf (last access: 23 November 2016), 2015.

Herron, M. M. and Langway Jr., C. C.: Firn densification: an empirical model, J. Glaciol., 25, 373-385, 1980.

Jacobs, S. S., Jenkins, A., Giulivi, C. F., and Dutrieux, P.: Stronger ocean circulation and increased melting under Pine Island Glacier ice shelf, Nat. Geosci., 4, 519-523, https://doi.org/10.1038/ngeo1188, 2011.

Jenkins, A.: Convection-Driven Melting near the Grounding Lines of Ice Shelves and Tidewater Glaciers, J. Phys. Oceanogr., 41, 2279-2294, https://doi.org/10.1175/JPO-D-11-03.1, 2011. 
Jenkins, A., Corr, H. F., Nicholls, K. W., Stewart, C. L., and Doake, C. S.: Interactions between ice and ocean observed with phasesensitive radar near an Antarctic ice-shelf grounding line, J. Glaciol., 52, 325-346, 2006.

Jeong, S., Howat, I. M., and Bassis, J. N.: Accelerated ice shelf rifting and retreat at Pine Island Glacier, West Antarctica, Geophys. Res. Lett., 43, 11720-11725, https://doi.org/10.1002/2016GL071360, 2016.

Jones, R. W., Renfrew, I. A., Orr, A., Webber, B. G. M., Holland, D. M., and Lazzara, M. A.: Evaluation of four global reanalysis products using in situ observations in the Amundsen Sea Embayment, Antarctica: Amundsen Sea Reanalyses Evaluation, J. Geophys. Res.-Atmos., 121, 6240-6257, https://doi.org/10.1002/2015JD024680, 2016.

Joughin, I., Smith, B. E., and Holland, D. M.: Sensitivity of 21st century sea level to ocean-induced thinning of Pine Island Glacier, Antarctica, Geophys. Res. Lett., 37, L20502, https://doi.org/10.1029/2010GL044819, 2010.

Joughin, I., Shean, D. E., Smith, B. E., and Dutrieux, P.: Grounding line variability and subglacial lake drainage on Pine Island Glacier, Antarctica, Geophys. Res. Lett., 43, 9093-9102, https://doi.org/10.1002/2016GL070259, 2016.

Langley, K., von Deschwanden, A., Kohler, J., Sinisalo, A., Matsuoka, K., Hattermann, T., Humbert, A., Nøst, O. A., and Isaksson, E.: Complex network of channels beneath an Antarctic ice shelf, Geophys. Res. Lett., 41, 1209-1215, https://doi.org/10.1002/2013GL058947, 2014.

Larson, K. M.: GPS interferometric reflectometry: applications to surface soil moisture, snow depth, and vegetation water content in the western United States: GPS interferometric reflectometry, Wiley Interdiscip. Rev. Water, 3, 775-787, https://doi.org/10.1002/wat2.1167, 2016.

Larson, K. M. and Nievinski, F. G.: GPS snow sensing: results from the EarthScope Plate Boundary Observatory, GPS Solut., 17, 4152, https://doi.org/10.1007/s10291-012-0259-7, 2013.

Larson, K. M., Wahr, J., and Kuipers Munneke, P.: Constraints on snow accumulation and firn density in Greenland using GPS receivers, J. Glaciol., 61, 101-114, https://doi.org/10.3189/2015JoG14J130, 2015.

Lazzara, M. A., Weidner, G. A., Keller, L. M., Thom, J. E., and Cassano, J. J.: Antarctic Automatic Weather Station Program: 30 Years of Polar Observation, B. Am. Meteorol. Soc., 93, 15191537, https://doi.org/10.1175/BAMS-D-11-00015.1, 2012.

Lenaerts, J. T. M., van den Broeke, M. R., van de Berg, W. J., van Meijgaard, E. and Kuipers Munneke, P.: A new, high-resolution surface mass balance map of Antarctica (1979-2010) based on regional atmospheric climate modeling, Geophys. Res. Lett., 39, L04501, https://doi.org/10.1029/2011GL050713, 2012.

Ligtenberg, S. R. M., Helsen, M. M., and van den Broeke, M. R.: An improved semi-empirical model for the densification of Antarctic firn, The Cryosphere, 5, 809-819, https://doi.org/10.5194/tc-5809-2011, 2011.

Medley, B., Joughin, I., Smith, B. E., Das, S. B., Steig, E. J., Conway, H., Gogineni, S., Lewis, C., Criscitiello, A. S., McConnell, J. R., van den Broeke, M. R., Lenaerts, J. T. M., Bromwich, D. H., Nicolas, J. P., and Leuschen, C.: Constraining the recent mass balance of Pine Island and Thwaites glaciers, West Antarctica, with airborne observations of snow accumula- tion, The Cryosphere, 8, 1375-1392, https://doi.org/10.5194/tc8-1375-2014, 2014.

Medley, B., Ligtenberg, S. R. M., Joughin, I., Van Den Broeke, M. R., Gogineni, S., and Nowicki, S.: Antarctic firn compaction rates from repeat-track airborne radar data: I. Methods, Ann. Glaciol., 56, 155-166, https://doi.org/10.3189/2015AoG70A203, 2015.

Moholdt, G., Padman, L., and Fricker, H. A.: Basal mass budget of Ross and Filchner-Ronne ice shelves, Antarctica, derived from Lagrangian analysis of ICESat altimetry: Ice shelf basal melting from altimetry, J. Geophys. Res. Earth-Surf., 119, 2361-2380, https://doi.org/10.1002/2014JF003171, 2014.

Mouginot, J., Rignot, E., and Scheuchl, B.: Sustained increase in ice discharge from the Amundsen Sea Embayment, West Antarctica, from 1973 to 2013, Geophys. Res. Lett., 41, 1576-1584, https://doi.org/10.1002/2013GL059069, 2014.

Nievinski, F. G.: Forward and inverse modeling of GPS multipath for snow monitoring, University of Colorado, available at: http://xenon.colorado.edu/portal/publications/Nievinski_ 2013_PhD.pdf (last access: 9 December 2016), 2013.

Padman, L., Fricker, H. A., Coleman, R., Howard, S., and Erofeeva, L.: A new tide model for the Antarctic ice shelves and seas, Ann. Glaciol., 34, 247-254, 2002.

Padman, L., King, M., Goring, D., Corr, H., and Coleman, R.: Ice-shelf elevation changes due to atmospheric pressure variations, J. Glaciol., 49, 521-526, https://doi.org/10.3189/172756503781830386, 2003.

Pavlis, N. K., Holmes, S. A., Kenyon, S. C., and Factor, J. K.: The development and evaluation of the Earth Gravitational Model 2008 (EGM2008), J. Geophys. Res., 117, B04406, https://doi.org/10.1029/2011JB008916, 2012.

Pritchard, H. D., Arthern, R. J., Vaughan, D. G., and Edwards, L. A.: Extensive dynamic thinning on the margins of the Greenland and Antarctic ice sheets, Nature, 461, 971-975, https://doi.org/10.1038/nature08471, 2009.

Pritchard, H. D., Ligtenberg, S. R. M., Fricker, H. A., Vaughan, D. G., van den Broeke, M. R., and Padman, L.: Antarctic ice-sheet loss driven by basal melting of ice shelves, Nature, 484, 502-505, https://doi.org/10.1038/nature10968, 2012.

Rietbroek, R., Brunnabend, S.-E., Kusche, J., Schröter, J., and Dahle, C.: Revisiting the contemporary sea-level budget on global and regional scales, P. Natl. Acad. Sci. USA, 113, 1504 1509, 2016.

Rignot, E.: Changes in West Antarctic ice stream dynamics observed with ALOS PALSAR data, Geophys. Res. Lett., 35, L12505, https://doi.org/10.1029/2008GL033365, 2008.

Rignot, E., Jacobs, S., Mouginot, J., and Scheuchl, B.: IceShelf Melting Around Antarctica, Science, 341, 266-270, https://doi.org/10.1126/science.1235798, 2013.

Rignot, E., Mouginot, J., Morlighem, M., Seroussi, H., and Scheuchl, B.: Widespread, rapid grounding line retreat of Pine Island, Thwaites, Smith, and Kohler glaciers, West Antarctica, from 1992 to 2011, Geophys. Res. Lett., 41, 3502-3509, https://doi.org/10.1002/2014GL060140, 2014.

Savage, J. C., Gan, W., and Svarc, J. L.: Strain accumulation and rotation in the Eastern California Shear Zone, J. Geophys. Res.-Sol Ea., 106, 21995-22007, https://doi.org/10.1029/2000JB000127, 2001. 
Scott, J. B. T., Gudmundsson, G. H., Smith, A. M., Bingham, R. G., Pritchard, H. D., and Vaughan, D. G.: Increased rate of acceleration on Pine Island Glacier strongly coupled to changes in gravitational driving stress, The Cryosphere, 3, 125-131, https://doi.org/10.5194/tc-3-125-2009, 2009.

Shabtaie, S. and Bentley, C. R.: Tabular icebergs: implications from geophysical studies of ice shelves, J. Glaciol., 28, 413-430, 1982.

Shean, D.: Quantifying ice-shelf basal melt and ice-stream dynamics using high-resolution DEM and GPS time series, PhD thesis, University of Washington, Seattle, WA, 14 July, available at: https://digital.lib.washington.edu:443/researchworks/handle/ 1773/36365, last access: 22 November 2016.

Shean, D. E., Alexandrov, O., Moratto, Z. M., Smith, B. E., Joughin, I. R., Porter, C., and Morin, P.: An automated, opensource pipeline for mass production of digital elevation models (DEMs) from very-high-resolution commercial stereo satellite imagery, ISPRS J. Photogramm. Remote Sens., 116, 101-117, https://doi.org/10.1016/j.isprsjprs.2016.03.012, 2016.

Shepherd, A., Ivins, E. R., A, G., Barletta, V. R., Bentley, M. J., Bettadpur, S., Briggs, K. H., Bromwich, D. H., Forsberg, R., Galin, N., Horwath, M., Jacobs, S., Joughin, I., King, M. A., Lenaerts, J. T. M., Li, J., Ligtenberg, S. R. M., Luckman, A., Luthcke, S. B., McMillan, M., Meister, R., Milne, G., Mouginot, J., Muir, A., Nicolas, J. P., Paden, J., Payne, A. J., Pritchard, H., Rignot, E., Rott, H., Sorensen, L. S., Scambos, T. A., Scheuchl, B., Schrama, E. J. O., Smith, B., Sundal, A. V., van Angelen, J. H., van de Berg, W. J., van den Broeke, M. R., Vaughan, D. G., Velicogna, I., Wahr, J., Whitehouse, P. L., Wingham, D. J., Yi, D., Young, D., and Zwally, H. J.: A Reconciled Estimate of Ice-Sheet Mass Balance, Science, 338, 1183-1189, https://doi.org/10.1126/science.1228102, 2012.

Stanton, T. P., Shaw, W. J., Truffer, M., Corr, H. F. J., Peters, L. E., Riverman, K. L., Bindschadler, R., Holland, D. M.m and Anandakrishnan, S.: Channelized Ice Melting in the Ocean Boundary Layer Beneath Pine Island Glacier, Antarctica, Science, 341, 1236-1239, https://doi.org/10.1126/science.1239373, 2013.
Van Meijgaard, E., Van Ulft, L. H., Van de Berg, W. J., Bosveld, F. C., Van den Hurk, B., Lenderink, G.m and Siebesma, A. P.: The KNMI regional atmospheric climate model RACMO version 2.1, Koninklijk Nederlands Meteorologisch Instituut, available at: http://www.weeralarm.nl/publications/fulltexts/tr302_ racmo2v1.pdf (last access: 31 May 2013), 2008.

Van Wessem, J. M., Reijmer, C. H., Morlighem, M., Mouginot, J., Rignot, E., Medley, B., Joughin, I., Wouters, B., Depoorter, M. A., Bamber, J. L., Lenaerts, J. T. M., De Van Berg, W. J., Van Den Broeke, M. R., and Van Meijgaard, E.: Improved representation of East Antarctic surface mass balance in a regional atmospheric climate model, J. Glaciol., 60, 761-770, https://doi.org/10.3189/2014JoG14J051, 2014.

Vaughan, D. G., Corr, H. F. J., Bindschadler, R. A., Dutrieux, P., Gudmundsson, G. H., Jenkins, A., Newman, T., Vornberger, P., and Wingham, D. J.: Subglacial melt channels and fracture in the floating part of Pine Island Glacier, Antarctica, J. Geophys. Res., 117, F03012,https://doi.org/10.1029/2012JF002360, 2012.

Webber, B. G. M., Heywood, K. J., Stevens, D. P., Dutrieux, P., Abrahamsen, E. P., Jenkins, A., Jacobs, S. S., Ha, H. K., Lee, S. H., and Kim, T. W.: Mechanisms driving variability in the ocean forcing of Pine Island Glacier, Nat. Commun., 8, 14507, https://doi.org/10.1038/ncomms14507, 2017.

Wouters, B., Martin-Espanol, A., Helm, V., Flament, T., van Wessem, J. M., Ligtenberg, S. R. M., van den Broeke, M. R., and Bamber, J. L.: Dynamic thinning of glaciers on the Southern Antarctic Peninsula, Science, 348, 899-903, https://doi.org/10.1126/science.aaa5727, 2015. 